\title{
(NE)ROZLUČNÍ SPOLEČNÍCI. POLOZAPOMENUTÉ IKONOGRAFICKÉ I URBANISTICKÉ SOUVISLOSTI VYBRANÝCH SOCHAŘSKÝCH DĚL VĚNOVANÝCH SV. JANU NEPOMUCKÉMU V PRAZE
}

\author{
KATEŘINA ADAMCOVÁ \\ Ústav pro dějiny umění Filozofické fakulty Univerzity Karlovy \\ katerina.adamcova@ff.cuni.cz
}

\begin{abstract}
(In)separable companions. Half-forgotten iconographic and urban contexts of selected sculptures dedicated to St. John of Nepomuk in Prague

The article deals with several statues of St. John of Nepomuk, which were created on the territory of the former Prague cities between the erection of the statue of a saint on Charles Bridge in 1683 and his beatification in 1721. Based on a deeper analysis of available data found both in the existing literature and on these statues themselves, and evaluation of their former urban context, the author points out an interesting phenomenon that is associated with these statues.

Keywords: Prague - Baroque sculpture - statues of St. John Nepomuk - former urban context
\end{abstract}

Kamenosochařská díla umístěná v exteriéru jsou z pohledu základního rozdělení kulturních památek na nemovité a movité obvykle řazena mezi památky nemovité, a to navzdory tomu, že individuální dějiny mnohých $\mathrm{z}$ nich této klasifikaci vůbec neodpovídají. Často se totiž stává, že jsou v průběhu své existence přeosazena, posunuta, transferována na nové stanoviště nebo dokonce zcela vysídlena, to znamená přesunuta do lokality, s níž nemají nic společného. ${ }^{1}$ To, že jsou statue, sousoší, ale i monumentální projekty typu mariánských, trojičních a dalších světeckých sloupů a piliŕů považovány za památky nemovité, neodráží tedy tolik jejich reálnou situaci, jako spíše skutečnost, že všichni, at už vědomě, či pouze intuitivně, vnímáme, že tato díla jsou nějak spojena s místem, na němž byla kdysi dávno postavena. I když se zejména v poslední době objevilo několik odborných publikací, jejichž autoři se pokoušejí zachytit toto sepětí sochařského díla s daným místem, ${ }^{2}$ stále není interpretace sochařských děl v širších urbanistických či krajinných

1 Mezi takové příklady patří, kromě celé plejády soch transferovaných z obcí likvidovaných v souvislosti s těžbou hnědého uhlí v oblasti Podkrušnohoří, také sousoší sv. Jana Nepomuckého, které stávalo na Václavském náměstí a které bylo přeneseno do obce Žebrák. Emanuel Poche et al., Umělecké památky Čech 4 (T/Ž), Praha 1982, s. 403.

2 František Svoboda et al., Krajina jako dílo. Barokní krajinou od Mikulova po Znojmo, Brno 2016, zvláště s. 146-182, kapitola Plenérová oratoria. - Kristýna Drápalová, Rekonstrukce krajiny. Mostecká pánev koncem 18. století, Zprávy památkové péče LXXVII, 2017, s. 10-17. - Kateřina Adamcová, Sochy v ba- 
souvislostech žádnou samozřejmostí. Přitom hlubší analýza zasazení dané statue, sousoší či sloupu do již existujícího krajinného či urbanistického rámce nám může přinést množství zajímavých informací týkajících se nejen historie vzniku daného díla, jeho prvotního významu, ale i jeho následujícího života.

Jedním z leitmotivů českého baroka je zrození nového světce, sv. Jana Nepomuckého. Rozporuplný příběh někdejšího generálního vikáře z dob Václava IV. byl zatím nejpodrobněji a nejbarvitěji popsán Vítem Vlnasem. ${ }^{3}$ Ten se ve své knize věnované tomuto světci nezabýval pouze samotným vznikem jeho kultu, spletitými dějinami beatifikačního a kanonizačního procesu, ale také celou řadou doprovodných jevů, nevyjímaje ani to, jak tento fenomén zasáhl do dějin výtvarného umění té doby. ${ }^{4}$ Vzhledem $\mathrm{k}$ hlavnímu zaměření jeho zevrubně pojaté studie se však samozřejmě nemohl dotknout všeho, co osudy nového českého zemského patrona provázelo.

$\mathrm{V}$ následujícím příspěvku bych chtěla poukázat na jeden $\mathrm{z}$ takových doprovodných mikro-př́běhů. Jeho hlavními aktéry jsou statue, které byly v Praze postaveny ještě před beatifikací Jana Nepomuckého, přičemž prvotní impuls pro identifikaci daného fenoménu vyšel právě z analýzy zasazení dotčených sochařských děl do daného urbanistického rámce. Hned na úvod je třeba poznamenat, že žádná z dotčených sochařských děl, jimiž se zde chci zabývat, dnes nestojí na svém původním místě. Jejich někdejší prostorový kontext bylo tedy třeba rekonstruovat, $\mathrm{k}$ čemuž jsem využila nejen popisy původního umístění soch světce zachycené ve starší topografické literatuře, ale také dostupné mapové podklady, zvláště pak Hergetův plán Prahy, Jüttnerův plán Prahy a někdy také originální otisky císařského stabilního katastru. Získané informace jsem pak porovnala s tím, co lze vyčíst z celkového rozvrhu daných statuí, ale i z detailů jejich architektonické i sochařské části včetně př́ípadných dochovaných votivních nápisů.

\section{Prolog}

Nejslavnějším sochařským zobrazením sv. Jana Nepomuckého je socha světce osazená na zábradlí Karlova mostu v roce domnělého třístého výročí jeho mučednické smrti. ${ }^{5}$

rokní krajině: panství Jezeří-Nové Sedlo, Zprávy památkové péče LXXVII, 2017, s. 36-46. - Kateřina Adamcová - Pavel Zahradník, Mariánský sloup na Hradčanském náměstí, Praha 2017, s. 115-132. Z dřívějších publikací takové pokusy najdeme zejména v textech Mojmíra Horyny, Petra Macka a Jana Hendrycha. Srovnej in: Mojmír Horyna, Baroko v české krajině a historické paměti, in: Vít Vlnas (ed.), Sláva barokní Čechie. Umění, kultura a společnost 17. a 18. století, Praha 2001, s. 249-255. - Jan Hendrych, Krajina bývalého nadačního panství Choustníkovo Hradiště, její př́iběh, proměny a souvislosti, péče o historickou krajinu světového významu, Zprávy památkové péće LXVIII, 2008, s. 302-308. - Petr Macek, Barokní krajinná řešení na toskánských panstvích, in: Kompozice zahrad, Praha 1987, s. 74 a n.

3 Vít Vlnas, Jan Nepomucký: česká legenda, vyd. 2., podstatně rozšířené a přepracované, Praha 2013. Dále také in: Vít Vlnas, Jan Nepomucký, světec baroka aneb druhý život Johánka z Pomuku, in: Václav Chroust - Zdeňka Buršíková - Karel Viták, (eds), Pět hvězd nad českým královstvím: svatý Jan Nepomucký a katolická reformace. 1, Klatovy 2013, s. 49-78. - Svatý Jan Nepomucký 1393 * 1993, katalog výstavy Bavorského národního muzea v Mnichově ve spolupráci s klášterem premonstrátů na Strahově v Praze a s Národním muzeem v Praze, Praha 1993.

4 Ibidem.

5 K dějinám vzniku této sochy naposledy in: Tomáš Hladík, Sochařská výzdoba, in: Ondřej Šefců (ed.), Karlìv most, Praha 2010, s. 188-189. - Jan Royt, Jan Nepomucký, in: Ondřej Šefců (ed.), Karlưv most, Praha 2010, s. 177-180. Nejpodrobněji pak in: Vlnas, Jan Nepomucký: česká legenda (pozn. 3), s. $220-225$. 
Ačkoliv bylo vztyčení této sochy více méně v rozporu s tehdy platnými církevními předpisy, ${ }^{6}$ stalo se paradoxně právě toto dílo nejen dalším důležitým centrem rodícího se kultu sv. Jana, ale společně s několika dalšími sochami a obrazy budoucího světce také důležitým dokladem všeobecné a dlouhotrvající úcty ke svatovítskému kanovníkovi, jež byla jednou z klíčových podmínek pro zahájení procesu jeho blahořečení. ${ }^{7} \mathrm{Na}$ působivosti tohoto díla, které se stalo podnětem $k$ první vlně vztyčování soch tohoto světce, se podílelo jak zvolené umístění pomníku ve střední části v té době jediného kamenného mostu v Praze, tak zdařilé výtvarné řešení sochařské části díla stejně jako jeho podstavce, jež oboje reflektuje nevšední urbanistický kontext. ${ }^{8}$

Po postavení mostecké sochy nastala v Praze poměrně dlouhá odmlka, protože další sochařská díla zobrazující Jana Nepomuckého se na veřejných prostranstvích tehdejších měst pražských začala objevovat teprve od roku 1709. Proč až tehdy a proč právě v tomto roce, zatím těžko s jistotou soudit. ${ }^{9}$ Co je však nezpochybnitelné a současně pozoruhodné, je skutečnost, že většinu soch sv. Jana Nepomuckého, které v Praze vznikly v období mezi postavením bronzové sochy světce na Karlově mostě a beatifikací sv. Jana v roce 1721, doprovází druhá světecká socha. Navíc vzniklé dvojice světeckých statuí, nejsou nahodilé, ale vytvářejí ikonografickým programem, ale mnohdy i specifickou výtvarnou formou propojený celek se zajímavým urbanistickým dopadem. Platí to jak v těch př́ípadech, v nichž byla socha druhého světce vztyčena současně s tou, jež připomíná sv. Jana Nepomuckého, tak i v tom př́padě, když socha druhého světce vznikla až s jistým časovým odstupem.

\section{Případ první - socha sv. Jana Nepomuckého u kostela sv. Jindřicha}

Ve zmíněném roce 1709 byly shodou okolností v Praze vztyčeny hned dvě sochy sv. Jana. První z nich dnes stojí po levé straně hlavního vstupního portálu do kostela sv. Jindřicha na Novém Městě a jejím protějškem je socha sv. Judy Tadeáše..$^{10}$ Obě statue

${ }^{6}$ Vít Vlnas zde zmiňuje breve papeže Urbana VIII., které zpřísňovalo dosavadní předpisy pro blahořečení a svatořečení, ale také vymezovalo přesněji hranice pro projevy úcty $\mathrm{k}$ zatím ještě nekanonizovaným a nebeatifikovaným světcům v podobě soch a obrazů. Srovnej in: Vlnas, Jan Nepomucký: česká legenda (pozn. 3), s. 124-125.

7 Na tuto skutečnost poukázal už Vít Vlnas. Srovnej in: Vlnas, Jan Nepomucký: česká legenda (pozn. 2), s. 120.

${ }^{8}$ K významu této sochy např. in: Vít Vlnas (pozn. 3), s. 220. Dále také in: Royt (pozn. 5). - Peter Volk, Sochy sv. Jana Nepomuckého. Poznámky k typům vyobrazení, in: Svatý Jan Nepomucký 1393 * 1993 (pozn. 3). - Jan Royt, Sv. Jan Nepomucký a jeho úcta v Praze, in: ibidem, s. 83.

9 Rok 1709 ani rok 1708 z pohledu formování kultu světce či průběhu př́prav na jeho blahořečení nijak významné nejsou. Určité mezníky představují rok 1706 a 1710. V roce 1706 podal papeži žádost o zahájení beatifikačního procesu tehdejší probošt pražských theatinů Jan Hložek ze Žampachu. Jednalo se o soukromou iniciativu, které se nedostalo posvěcení z oficiálních míst a mimo to byla neúspěšná. $\mathrm{V}$ roce $1710 \mathrm{k}$ témuž vyzval tehdejšího arcibiskupa pražského Jana Josefa Breunnera panující císař Josef I. Arcibiskup Breunner ovšem krátce nato umírá a beatifikační žádost tak podal až jeho nástupce arcibiskup František Ferdinand Kühnburg, kterému se proces beatifikace podařilo dovést do úspěšného konce. Viz Vlnas, Jan Nepomucký: česká legenda (pozn. 3), s. 132.

10 Naposledy in: Jana Tischerová, Matěj Václav Jäckel. Sochař českého baroka 1655-1738, Praha 2013, s. 412-414. Jana Tischerová se sochami zabývá v části nazvané Katalog mylně připsaných děl, mimo jiné zde uvádí kompletní historii atribuce obou soch, spojovaných v minulosti jak s ateliérem Jana Brokoffa, tak právě s dílnou $\mathrm{M}$. V. Jäckela, a to včetně príslušných odkazů na dosavadní literaturu. 
byly pořízeny zároveň, a to na náklady tehdejšího faráře u sv. Jindřicha Matěje Václava Jelínka. ${ }^{11}$ Původně byly tedy především projevem jeho osobní zbožnosti a úcty k oběma světcům. Ovšem díky celkovému pojetí obou statuí a zejména díky jejich specifickému umístění získala tato dvojice význam, který výrazně přesahuje ryze osobní rovinu.

Sochy dnes rámují vstup do kostela. Sem ale byly přeneseny až po zrušení hřbitova, který do sklonku 18. století kostel sv. Jindřicha obklopoval. Někdejší prostorovou situaci tohoto páru soch, popsanou mimo jiné v Posvátných místech Prahy od Františka Ekerta, ${ }^{12}$ můžeme nyní vyčíst z Hergetova plánu, na němž je zed’ lemující bývalý kostelní hřbitov se vstupní bránou orientovanou do Jindřišské ulice ještě zakreslena. ${ }^{13} \mathrm{Na}$ tomto plánovém podkladu je mimo jiné patrné, že prostranství hřbitova zasahovalo hluboko do ulice a že vstupní brána na hřbitov díky tomu fungovala ze směru $\mathrm{z}$ někdejšího Koňského trhu, dnešního Václavského náměstí, jako svého druhu point de vue. Kdysi prostý vstup na hřbitov se tak poté, co byla osazen sochami tyčícími se na vrcholu nesmírně masivních, dnes ve vztahu $\mathrm{k}$ měřítku soch podivně působících podstavců, ${ }^{14}$ proměnila ve výrazný urbanistický prvek. ${ }^{15}$

Kromě charakteru původního stanoviště těchto soch jsou dalším důležitým vodítkem pro pochopení toho, jakou úlohu v rámci daného místa původně plnily, latinské nápisy, které nechal jejich donátor vysekat na čelní strany podstavců. Pod sochou sv. Jana v překladu čteme: „Slavnému / ochránci pověsti / pražskému / kanovníkovi / kněžská / zbožnost / dala / dne 13. července“16 a pod sochou sv. Judy Tadeáše: „Svatému Tadeášovi / velkému apoštolovi / príteli Kristovu / ve věcech beznadějných [či ztracených] / ochránci / na / znamení vděčnosti / postaveno. "17

Nápis na podstavci se sochou sv. Jana dokládá, jak se postupně transformoval prvotní patronát světce související s uchováním zpovědního tajemství, jež bylo připomenuto

11 K tomu nejlépe František Ekert, Posvátná mista královského hlavního města Prahy. Dějiny a popsání chrámů, kaplí, posvátných soch, klášterů a jiných pomniků katolické víry a nábožnosti v hlavním mèstě království Ceského II, Praha 1884, s. 15.

12 Ekert tu nejspíše vyšel z knihy Karla Navrátila věnované kostelu sv. Jindřicha a Kunhuty z roku 1869. Ten totiž stejně jako později Ekert uvádí, že samotný hřbitov byl sice zrušen již roku 1787, ovšem sochy byly ke kostelu přeneseny až roku 1827. To znamená, že úprava okolí kostela sv. Jindřicha vzniklá na začátku 18. století určovala podobu této části Jindřišské ulice víc jak sto let. Srovnej Karel Navrátil, Paměti hlavního kostela farního, fary a školy sv. Jindřicha a sv. Kunhuty v Novém Městě pražském, Praha 1869, s. 146-147. - Ekert (pozn. 11).

13 Srovnej in: http://towns.hiu.cas.cz/p_zoom.php?map=AMP_Herget_1791, vyhledáno dne 25. 5 . 2020. Na mladším Jüttnerově plánu z roku 1816 již vypadá prūběh ohradní zdi trochu jinak. Srovnej in: http://mapy.vugtk.cz/praha/sheets.php?rs=1\&id=00\&map=juttner\&print, vyhledáno dne 21. 2 . 2020. Starší plán J. D. Hubera z roku 1769 bohužel díky tomu, jak je zpracován, danou situaci rozečíst neumožňuje. Siluety kostela sv. Jindřicha a domů v Jindřišské ulici zakrývají výhled na daný úsek zdi kolem hřbitova. Srovnej in: http://www.digitalniknihovna.cz/mlp/view/uuid:cd5fb450-cdbc -11dd-b222-0030487be43a?page=uuid:27d8fdd0-cdc0-11dd-8632-0030487be43a, vyhledáno dne 23. 9. 2020.

14 Ve chvíli, kdy si uvědomíte, že se vlastně jednalo o pilíře rámující vstup na hřbitov, už tyto podstavce tak nepřiměřeně masivně ve vztahu k sochám nepưsobí.

15 Připomeňme, že tato ulice vedla nejen k novoměstskému kostelu, ale také k bráně oddělující Nové Město od „předměstí, a byla tak jednou z důležitých komunikačních spojnic této části tehdejší Prahy.

16 V originálu: „GLORIOSO / FAME PATRONO / PRAGENSI / CANONICO / SANCTO IOANNI / ECCLESIASTICA / PIETAS / PONIT / DIE XIII IULY“. V chronogramu je ukryt rok 1709.

17 V originálu: „DIVO THADAEO / MAGNO APOSTOLO / AMICO CHRISTI / IN / CAVSIS DESPERATIS / PATRONO / IN GRATITUDINIS TESSERAM / POSITUM“ (bez chronogramu). Přepisy obou nápisů nabízí také ve své knize Navrátil. Viz Navrátil (pozn. 12), s. 147. Ten rovněž přináší další podrobnosti z jejich následujícího osudu týkajícího se následků pruského obležení Prahy v roce 1757. 
také na jednom z reliéfů na podstavci bronzové sochy světce na Karlově mostě. Jeho role ochránce toho, co mu bylo svěřeno v průběhu zpovědi, symbolizovaná později zejména zázračně dochovaným jazykem světce, objeveným při průzkumu jeho ostatků, jej předurčila pro to, aby se stal patronem dobré pověsti. A tady je třeba připomenout, že sv. Juda Tadeáš, kromě toho, že byl vzýván ve ztracených záležitostech, ${ }^{18}$ tedy ve chvíli, kdy už se zdálo, že není žádná naděje, byl rovněž patronem dobré pověsti a ochráncem proti pomluvě.

Spojenectví mezi oběma světci, které by se na první pohled mohlo zdát jako nepř́liš logické, má tedy naopak prosté vysvětlení. Stejně tak to, proč byli právě oni dva vybráni, aby vítali ty, kteří vstupovali bránou na zdejší farní hřbitov. Velmi pravděpodobně to souvisí s latinským úslovím, ${ }^{19}$ které platilo i v období baroka, tedy že o mrtvých se má mluvit jen dobře. To znamená, že ten, kdo vcházel na posvěcené místo, kde spočinuly ostatky těch, kteří už museli opustit toto slzavé údolí, byl skrze tyto sochy nabádán, aby upustil od klevetění a vzdal tak patřičnou úctu mrtvým, kteří se proti případné pomluvě nemohou nijak bránit.

Vedle této interpretace, $\mathrm{k}$ níž odkazuje zejména nápis pod sochou sv. Jana, se nabízí druhá, která vychází spíše z nápisu pod sochou sv. Judy Tadeáše a která souvisí s dobovým vztahem ke smrti. Osobnost sv. Judy Tadeáše měla působit jako mravní exemplum pro všechny, kteří by snad tváří tvář své vlastní smrtelnosti propadali zoufalství. Smrt je totiž v pojetí barokní zbožnosti nejen okamžikem, kdy končí náš pozemský život, ale především okamžikem, kdy se nám za předpokladu splnění určitých podmínek, mohou otevřít brány nebeské. Patronát sv. Jana týkající se zpovědního tajemství odkazuje rovněž ke zpovědi samotné, která je v katolickém vyznání důležitým prostředkem pro dosažení opětovného usmíření s Bohem a jako taková byla významnou součástí posledního pomazání, jež bylo předpokladem tzv. „dobré smrti“.

Dvojice soch rámujících kdysi vstupní bránu na hřbitov však nese ještě jeden důležitý motiv, který souvisí s postupným včleňováním sv. Jana Nepomuckého mezi světce. Ve dvojici se sv. Judou Tadeášem byl Jan Nepomucký představen jako svého druhu následovník apoštolů, jako ten, který usiloval o život v Kristu a který podobně jako apoštolové následoval Krista i ve smrti. Koncept znovuobnoveného zpo̊sobu života, který kdysi vedli apoštolové, tzn. šíření víry v Ježíše Krista v celém tehdy známém světě, a to i za cenu ztráty života, patří totiž k dalším charakteristickým rysům potridentské zbožnosti.

\section{Př́pad druhý - socha sv. Jana Nepomuckého u paty Radnických schodů}

Druhou ze soch sv. Jana, které se v Praze objevily v roce 1709, najdeme dnes u paty Radnických schodů na rozhraní Malé Strany a Hradčan. ${ }^{20} \mathrm{I} v$ př́padě této sochy se jednalo o soukromou donaci. Na základě Schottkym publikovaného pramene totiž víme, že vznikla na podnět neznámého dobrodince, za nějž žádost o udělení souhlasu k jejímu

18 K tomu např. in: James Hall, Slovník námětů a symbolů ve výtvarném umění, Praha 1991, s. 205.

19 Latinsky: „De mortuis nil nisi bene“.

20 K dějinám sochy nejlépe in: Oldřich Jakub Blažíček, Ferdinand Brokof, Praha 1986, s. 92. 
postavení podal na začátku března roku 1709 kameník František Jakub Santini-Aichel. ${ }^{21}$ Sochařská část statue byla vysekána $\mathrm{v}$ ateliéru Jana Brokoffa, jak to mimo jiné dosvědčuje signatura na zadní straně plintu sochy. ${ }^{22}$ Zda bylo celé dílo dokončeno ještě v roce podání žádosti nebo až následujícího roku, to bohužel s jistotou nevíme. Signaturu sochaře tentokrát nedoprovází datace ${ }^{23}$ a o samotném vztyčení či případném slavnostním svěcení díla prameny zatím mlčí. Obvykle je však i tato socha sv. Jana Nepomuckého datována právě do roku 1709. 24

Přestože byla statue sv. Jana u Radnických schodů druhou sochou doplněna až několik let po svém vzniku, konkrétně $\mathrm{v}$ roce $1714,{ }^{25} \mathrm{i} \mathrm{v}$ jejím případě můžeme mluvit o ikonograficky a urbanisticky významné kompozici, která navíc obsahuje některé motivy, jež se později budou objevovat $\mathrm{v}$ souvislosti se zobrazením tohoto nového světce poměrně často. Jedním z nich je již samotný výběr druhé světecké sochy. Protějškem sv. Jana je zde totiž postava sv. Josefa s malým Ježíškem v náručí.

Sv. Josef sice nepatří př́mo mezi nové světce, ale jeho kult se právě v období, které je $\mathrm{z}$ hlediska formování barokní zbožnosti klíčové, značně proměnil. ${ }^{26} \mathrm{~V}$ prvé řadě vzrostla obecná úcta $\mathrm{k}$ tomuto světci, ${ }^{27}$ a to dokonce do té míry, že získal téměř totožné postavení jako Panna Marie, resp. velmi podobné postavení, které v rámci svaté Rodiny již od středověku zastávala sv. Anna. V novém výkladu významu sv. Josefa v dějinách spásy byl položen důraz na jeho podíl na výchově budoucího Spasitele, na jeho roli pěstouna, někoho, kdo, ačkoliv nebyl rodičem, byl schopen stejné lásky i oběti. Díky této interpretaci se i sv. Josef stal, podobně jako Panna Marie, doslova klíčovou postavou dějin spásy, a nejen to. Současně plnil roli dokonalého mravního exempla otcovské či pěstounské lásky a péče, což výrazně obohatilo a rozšírilo jeho tradiční patronát zaměřený na tesaře, truhláře a další povolání, která se věnují práci se dřevem. ${ }^{28}$ Ve středoevropském prostoru posílilo jeho dosavadní postavení mezi světci také to, že byl krátce po polovině 17 . století oficiálně zařazen mezi české zemské patrony, ${ }^{29}$ a jako takový se např́iště objevoval kromě sv. Rodiny i v této mimořádně význačné skupině světců. A tady asi leží klíč k tomu, proč

21 Julius Max Schottky, Prag wie es war und wie es ist, nach Aktestücken und den besten Quellenschriften geschildert, Praha 1832, s. 279-280.

22 Zajímavé je, že se v Schottkym publikovaném přepisu výňatku z dané žádosti objevuje zmínka, že František Santini, který žádost podával, vytvoří danou sochu sám. V návaznosti na tento údaj je pak také v úvodu dané části textu věnované této soše Santini označen Schottkym jako sochař. Viz Schottky (pozn. 21), s. 279.

23 Zmiňujeme to zde proto, že valná většina signovaných sochařských děl pocházejících z brokoffovského ateliéru je také označena datací.

24 Oldřich Jakub Blažíček klade vznik soch opatrně do roku 1709-1710. Viz Blažíček (pozn. 20). Do roku 1709 ji však datuje jak Ekert, tak například zatím nejmladší publikovaný soupis památek na území Prahy. Viz Pavel Vlček (ed.), Umělecké památky Prahy. Pražský hrad a Hradčany, Praha 2000, s. 455.

25 Naposledy in: Vlček (ed.), (pozn. 24), s. 455. Statue vznikla na podnět a náklady Zikmunda Antona Herzoga a hlavní informace o jejím vzniku uvádí už Schottky, přičemž vychází opět z excerpovaných písemných pramenů. Viz Schottky (pozn. 21) s. 280.

26 Významný podíl na tom mají také význačné osobnosti 16. století, zakladatelé nových řádových společenství, mystikové a vyznavači, jako například sv. Terezie z Ávily. Srovnej in: Wolfgang Braunfels (ed.), Lexikon der christlichen Kunst, svazek 7, Rom-Freiburg-Basel-Wien 1994, s. 210-223.

27 Počátky proměny postavení sv. Josefa v rámci sv. Rodiny a tím i ve skupině světců obecně sahají až do 15. století, konkrétně do období konání koncilu Kostnického, kde tyto nové myšlenky vyslovil Jean Gerson. Srovnej in: Jan Royt, Slovník biblické ikonografie, Praha 2006, s. 102.

28 Braunfels (ed.), (pozn. 26).

29 Konkrétně v roce 1654. Viz Royt (pozn. 27). 
byla k soše sv. Jana Nepomuckého přiřazena právě socha sv. Josefa. I Jan Nepomucký byl totiž ještě před svou beatifikací včleněn mezi ochránce zemí Koruny české, ${ }^{30}$ a i on byl v této skupině svým způsobem „nováčkem“ ${ }^{31}$

Kromě propojení postavy sv. Jana se sv. Josefem je dvojice soch u Radnických schodů pozoruhodná také svým původním urbanistickým konceptem. Dnes stojí obě sochy na začátku schodiště, jehož osa je jakýmsi lehce posunutým pokračováním Nerudovy, kdysi Ostruhové, ulice, hlavní komunikační spojnice mezi Malou Stranou a Hradčany. ${ }^{32}$ Původně, a to až do roku 1820, ale obě sochy stály na začátku relativně nedávno zbudované rampy, která zajištovala prŕmé spojení mezi Malou Stranou a Hradčanským náměstím. ${ }^{33}$ I v jejich prrípadě je tak možné hovořit o tom, že na svém původním stanovišti tvořily jakousi slavobránu a že vítaly ty, kteří jeli nebo šli po této nejvýznamnější přístupové cestě na Pražský hrad směrem od Karlova mostu. A nejen to. Na svém někdejším stanovišti tyto sochy plnily také úlohu jakýchsi hraničních kamenů, oddělujících území v té době ještě samostatných měst, Hradčan a Malé Strany.

Přestože by se mohlo zdát, že i po přenesení obou statuí k patě Radnických schodů je jejich urbanistický význam a celkové vyznění podobné, při podrobnější prohlídce zjistíme, že na novém místě nepůsobí jejich kompoziční a modelační řešení ani zdaleka tak efektně a že možná i proto řadě kolemjdoucích dnes unikají některé podstatné momenty z jejich obsahového sdělení. Ostatně skutečnost, že výběr místa pro osazení obou soch nebyl nahodilý, dokládají také Schottkym citované archiválie. V žádosti týkající se sochy sv. Jana se můžeme dočíst, že toto dílo má sloužit nejen $\mathrm{k}$ tomu, aby vzdávalo úctu Bohu a šírilo oddanost ke sv. Janu Nepomuckému, ale také k okrase „Nové cesty“. ${ }^{34} \mathrm{~V}$ prípadě protějškové sochy sv. Josefa je zase v žádosti uvedeno, že socha má být postavena „na rohu 'Nové cesty', kde parapet stoupá vzhưru $k$ vjezdu do královského zámku právě proti soše sv. Jana Nepomuckého“. A osazena má být na dobrý podstavec tak, aby „nebyla porušena symetrie“ a současně tak, „aby byl roh parapetu zesílen a aby ani průchodu ani průjezdu dané dílo nebránilo".35

Z pohledu celkového řešení díla se statue sv. Josefa zdá být poměrně prostá. Podstavec představuje nijak zvlášt nápaditou variaci na klasický hranolový sokl, snad jen s tou výjimkou, že dřík podstavce je poměrně štíhlý a vysoký, což posiluje vertikalitu celku.

30 Sv. Jan Nepomucký je mezi českými zemskými patrony uváděn už okolo roku 1600, a to společně se sv. Ivanem, který byl $\mathrm{v}$ dané době také nově zařazen do této význačné skupiny světců.

31 Z obdobné ideové koncepce vychází například sousoší sv. Jana Nepomuckého v doprovodu sv. Václava a sv. Víta, které bylo vztyčeno v roce 1714 v Děčíně, nebo monumentální sousoší sv. Jana Nepomuckého postavené v Mostě, kde tohoto ještě nebeatifikovaného světce doprovázejí sv. Václav a sv. Vojtěch. K tomu naposledy in: Nataša Brejchová-Steinová, Zjánštěná item zjančená léta na Děčínsku, Okresní muzeum Děčín 2001, s. 15-16. Nataša Brejchová-Steinová se v dané kapitole věnuje podobné problematice, tj., jakým způsobem se ještě ne svatý světec objevoval na kamenosochařských dílech umístěných v exteriéru. Danou kapitolu nazvala s nadsázkou: "Pytlačení" před blahoslavením Jana.

32 K tomu nejlépe: František Ekert, Posvátná mista královského hlavního města Prahy. Dějiny a popsání chrámů, kaplí, posvátných soch, klášterů a jiných pomníku katolické víry a nábožnosti v hlavním městě království Ceského I, Praha 1883, s. 114.

33 Ještě na Hergetově plánu Prahy z roku 1791 je tato rampa označena jako „Neue weg“, tedy „Nová cesta“. Srovnej in: http://towns.hiu.cas.cz/p_zoom.php?map=AMP_Herget_1791, vyhledáno dne 25. 5. 2020.

34 Viz Schottky (pozn. 21), s. 279.

35 Viz Schottky (pozn. 21), s. 280. S frekventovaným pochozím a pojezdným provozem na této cestě souvisí nejspíše mohutné podnože obou statuí, které přerůstají v bochníkovité útvary, jež plnily funkci nákolníkủ a které na stávajícím stanovišti soch ztrácejí svůj smysl. 
O to více se však na vyznění statue podílí sochařsky velmi zdařilé provedení samotné sochy, v němž jeho autor ${ }^{36}$ položil důraz na zobrazení vzájemného cituplného rozhovoru sv. Josefa s malým Ježíškem v náručí. Kompozice sousoší založená na plynulé šroubovici gradující v horní polovině těla sv. Josefa přitom rezonuje nejsilněji v úseku mezi čelní a pravou boční stranou sochy, tj. na té části díla, která se dnes obrací ke zdi. Na původním stanovišti bylo toto sochařské dílo naopak touto částí orientováno do volného prostoru, a vysoce emocionální pojetí daného tématu tak mohlo poutat pozornost již těch, kteří teprve stoupali Ostruhovou ulicí.

Ještě výraznější rozdíl mezi původním a nynějším vyzněním daného díla můžeme nalézt u statue sv. Jana, a to proto, že scénický koncept, který se v jejím řešení prosadil nejen v sochařské, ale i architektonické části, ještě intenzivněji pracoval s charakterem původního stanoviště daného díla. Snaha o výraznější propojení statue s okolním prostorem se projevila $\mathrm{v}$ tomto díle již v tom, že postava sv. Jana Nepomuckého, která jinak v zásadě vychází ze zobrazení světce konstituovaného bronzovou sochou na Karlově mostě, byla obohacena o dvojici andílků. Jejich postavičky se svými pohyby totiž obracejí i do bočních stran statue a jako první tak navazují kontakt s kolemjdoucím. Kromě toho jsou však tito andílci nositeli dalších důležitých motivů, které rozvíjejí základní ikonografii sochy světce. ${ }^{37}$ Levý putto si klade prst na ústa, aby tak zdůraznil, že světec je patronem zpovědního tajemství, jehož zachování se stalo jednou z hlavních př́ičin jeho mučednické smrti. Vedle toho má na svém klíně položenou rozevřenou knihu, v níž je opakovaně vysekáno slovo „NON“ a „NEC NON“, tedy latinský zápor, jež samozřejmě znovu upozorňuje na skutečnost, že sv. Jan ani na mučidlech neprozradil, co mu bylo svěřeno při zpovědi. Pravý andílek pak s vážným výrazem ve tváři oběma rukama rozvíjí úzký, dlouhý foliant, na němž je vysekána silueta kamenného mostu, která odkazuje k místu, odkud bylo tělo světce svrženo do Vltavy.

Socha sv. Jana Nepomuckého u paty Radnických schodů však nenabízí pouze zajímavé a neotřelé sochařské ztvárnění daného tématu, ale také nový zpơsob provázání sochařského díla a architektury. Podstavec pod sochou je velmi zajímavě řešený, skutečně jen zdánlivě se jedná o prostý hranolový sokl. Rímsová hlavice uzavírající celkovou skladbu podstavce totiž vyrůstá plynule z jeho dř́ku a stejně plynule pak přechází v soklík vynášející plintus ústřední postavy světce. Výrazná hybnost a plasticita podstavce, daná uplatněním volně modelovaných takřka organicky působících tvarů, díky tomu plně souzní s řešením sochařské části celku. Mezi architekturou a sochařským dílem vzniká symbiotický vztah, který je typický pro díla označovaná v našem prostředí nejčastěji termínem „Gesamtkunstwerk“.38

36 Za autora této sochy bývá označován Matyáš Bernard Braun, resp. jeho dílna, jiní uvažují o bývalém tovaryšovi Ottavia Mosta. Srovnej in: Oldřich Jakub Blažíček, Sochařství baroku v Čechách, Praha 1958, s. 40, 275, pozn. 13. - Václav Vančura, Ottavio Mosto, Umění XLIII, Praha 1995, s. 338-353. Naposledy in: Pavel Vlček et al., Umělecké památky Prahy. Pražský hrad a Hradčany, Praha 2000, s. 455.

37 Většina badatelů si těchto doprovodných postaviček ve své analýze př́liš nevšímá, což je bohužel škoda. Stručně jejich význam v celkové ikonografii sochy popsal pouze Oldřich Jakub Blažíček. Ale ani on si nevšiml slov vysekaných v knize, kterou drží levý andílek.

38 Jediným srovnatelně řešeným dílem v té době Praze je sousoší sv. Anny na Karlově mostě, jehož podstavec je koncipován na základě stejných kompozičně-modelačních principů. Vzhledem $\mathrm{k}$ tomu, že $v$ př́padě sochy sv. Jana Nepomuckého u paty Radnických schodů zaznívá jméno kameníka Santiniho a v př́ípadě sv. Anny na Karlově mostě zase víme, že jejím byl donátorem staroměstský hejtman Rudolf Josef hrabě z Lissau, pro nějž navrhoval ve stejné době Jan Blažej Santini na Starém Městě 
Prvky, které vypovídají zřetelně o těsném provázání kompozičního rozvrhu celé statue s pưvodním stanovištěm, najdeme ovšem nejen v sochařské části statue, ale i na podstavci. Podobně jako byly postavičky andílků komponovány tak, aby k soše světce poutaly pozornost $\mathrm{z}$ bočních směrů, tak i architektura podstavce nabízela na svých bočních stranách cosi navíc. Právě boční strany dříku soklu jsou totiž na rozdíl od strany čelní opatřeny vystouplými oblamovanými poli, které pravděpodobně původně nesly nebo možná pouze měly nést malované votivní nápisy, jak to známe $\mathrm{z}$ jiných sochařských děl, kde se tato část celkového sdělení díla zachovala. ${ }^{39}$

Zatímco u kostela sv. Jindřicha byl sv. Jan představen jako jeden z následovníků apoštolského způsobu života a smrti, na začátku rampy vedoucí k Pražskému hradu byl ve společnosti se sv. Josefem prezentován jako jeden z ochránců Království českého. Krátce nato se jeho postava objevila ve stejné skupině světců na nedaleko odsud stojícím trojičním sloupu na Malostranském náměstí. ${ }^{40} \mathrm{Na}$ tomto monumentu ovšem na sebe čeští zemští patroni vzali úlohu, kterou na předchozích dílech tohoto typu plnili světci patřící mezi hlavní ochránce proti moru, jako jsou sv. Roch, sv. Rosálie, sv. František Xaverský nebo sv. Šebestián. A v této nové roli, protimorového patrona, jej pak najdeme i na dalších dvou morových sloupech vztahujících se k epidemii, jež Prahou prošla v letech 1713-1714, trojičním sloupu, jenž nechal postavit hrabě František Antonín Špork nedaleko kostela sv. Štěpána na Novém Městě, ale i mariánském sloupu vztyčeném na Hradčanském náměstí.

\section{Případ třetí - socha sv. Jana Nepomuckého na nádvoří kostela Panny Marie Sněžné}

Zařazení sv. Jana Nepomuckého mezi „protimorové patrony“, které se nejvíce projevilo v jeho zobrazování na morových sloupech a pilírích, ${ }^{41}$ dokumentuje další zajímavá světecká dvojice. $V$ tomto př́padě obě statue tvořící pár vznikly opět současně, a to v roce

nový palác, asi můžeme předpokládat, že se na obou těchto statuích skutečně podíleli členové rodiny Santini. K osobnosti kameníka Františka Jakuba Santiniho viz Pavel Vlček (ed.), Encyklopedie architektů, stavitelü, zedníků a kameníků v Čechách, Praha 2004, s. 11. K činnosti architekta Jana Blažeje Santiniho pro hraběte Rudolfa z Lissau nejlépe viz Mojmír Horyna, Jan Blažej Santini-Aichel, Praha 1998, s. 213.

39 Mezi taková díla, kde se tyto nápisy v úplnosti nebo alespoň částečně dochovaly, patř́i např́klad sochy světců na ohradní zdi kostela sv. Jana Křtitele v Lysé nad Labem nebo sochy dvanácti měsíců v tamějším zámeckém parku. Srovnej nejlépe in: Kateřina Adamcová, Sochy na ohradní zdi kostela sv. Jana Křtitele v Lysé nad Labem aneb „Když podstavce vyprávějí...", Památky středních Čech XXIX/1, Praha 2015, s. 1-15. - Kateřina Adamcová, Sochy v zámeckém parku v Lysé nad Labem, Acta Universitatis Carolinae, Philosophica et historica 1/2016, Studia historiae artium II, Praha 2016, s. 205-224.

40 Skupinu českých zemských patronů, která doplňuje Pannu Marii Immaculatu, zde tvoří sv. Václav a sv. Vojtěch, které najdeme na čelní straně, dále sv. Ludmila a sv. Jana Nepomucký na bočních stranách monumentu a nakonec sv. Prokop, který je umístěn na zadní straně. Sv. Vít tu sice není prítomen ve formě sochy, ale když totiž stojíte proti čelní straně sloupu, tak pozadí monumentu tvoří silueta chrámu sv. Víta na Pražském hradě.

41 Poprvé byl Jan Nepomucký jako patron proti moru prokazatelně vzýván již v roce 1649. Viz Franz Matsche, Náhrobek sv. Jana Nepomuckého v pražském chrámu sv. Víta jako sakrální památka, in: Svatý Jan Nepomucký $1393{ }^{*} 1993$ (pozn. 3), s. 48 a s. 59, pozn. 12. Matsche tady odkazuje na Balbínův životopis světce v Acta Sanctorum z roku 1680. 
1715. ${ }^{42}$ Jejich objednavatelem byl Jáchym hrabě Harrach, který chtěl vztyčením daných soch poděkovat za přestálou morovou ránu. Zmíněné statue najdeme v areálu kláštera františkánů při kostele Panny Sněžné na Novém Městě, kde v souvislosti s touto událostí byla ve stejné době postavena kaple Panny Marie Pomocné (Pasovské), jejíž vstup tyto sochy původně rámovaly. ${ }^{43}$

Kromě dalšího rozšiřrení dosavadního patronátu, vycházejícího původně zejména z uchování zpovědního tajemství, nám tato dvojice soch z pohledu postupné proměny postavení Jana Nepomuckého dokládá další, opět poměrně častý způsob, jímž byl Jan Nepomucký postupně včleňován mezi světce. Jedná se o způsob, hojně užívaný i u jiných „nových“ světců, a je založen na spojování nové osobnosti z dějin spásy se světcovými jmenovci. V následujících dějinách zobrazování sv. Jana Nepomuckého jej proto budeme vůbec nejčastěji potkávat v doprovodu sv. Jana Křtitele, nebo sv. Jana Evangelisty, či ještě lépe obou uvedených. Tady na nádvoří kostela Panny Marie Sněžné se Janovým souputníkem stal jiný jeho jmenovec, sv. Jan z Boha, ${ }^{44}$ jenž byl sám kanonizován teprve nedávno. ${ }^{45}$

Sv. Jan Nepomucký se zde ocitl ve společnosti nejvýznamnějšího člena řádu milosrdných bratří, společenství, které se věnovalo v prvé řadě péči o nemocné a umírající. ${ }^{46}$ V propojení Jana Nepomuckého se sv. Janem z Boha jako by se vyjevil jiný důležitý motiv $\mathrm{z}$ legendy světce, $\mathrm{v}$ němž jsou rozvíjeny další podstatné rysy jeho osobnosti. ${ }^{47} \mathrm{~V}$ pozdějších sochařských dílech bude sv. Jan Nepomucký často prezentován také jako almužník, ${ }^{48}$ tedy jako ten, jehož srdce je otevřené všem potřebným. ${ }^{49}$ Je možné, že sv. Jan Nepomucký a sv. Jan z Boha zde pravděpodobně mohli zosobňovat různé podoby Caritas, ${ }^{50}$ lásky

42 K historii vzniku této dvojice naposledy in: Růžena Batková et al., Umělecké památky Prahy. Nové Město, Vyšehrad, Vinohrady (Praha1), Praha 1998, s. 717. V hesle zpracovaném Václavem Vančurou je uveden odkaz na pramen uložený v SÚA.

${ }^{43} \mathrm{~K}$ tomu nejlépe in: Ekert (pozn. 11), s. 63-66.

${ }^{44}$ František Ekert určuje druhou sochu světce jako sv. Petra z Alcantary, nejspíše proto, že byl členem františkánského řádu. Viz Ekert (pozn. 11), s. 66. Jedná se však nepochybně o sochu sv. Jana z Boha. Postava světce je totiž oděna do řádového roucha milosrdných bratří, a ne do oděvu řádu patř́cích $\mathrm{k}$ františkánské observanci, a mimoto má na hlavě trnovou korunu, s níž stejně jako s křížem v ruce bývá sv. Jan z Boha na rozdíl od sv. Petra z Alcantary, zobrazován. Viz Batková (ed.), (pozn. 42), s. 717. - Luděk Jirásko, Církevní řády a kongregace v zemích českých, s. 53-59 a 73-74.

45 Blahořečen byl sv. Jan $\mathrm{z}$ Boha papežem Urbanem VIII. $\mathrm{v}$ roce 1630 a kanonizován pak papežem Alexandrem VIII. v roce 1690. Viz Petr Pracný, Český kalendár světců, Praha 1994, s. 54.

${ }^{46} \mathrm{~K}$ řádu milosrdných bratři viz Milan Buben, Encyklopedie rádů a kongregací v českých zemích, III. díl, sv. 2., Žebravé řády, Praha 2007.

47 K osobnosti sv. Jana z Boha, s níž je sv. Jan Nepomucký porovnáván, viz Pracný (pozn. 45). - James Hall, Slovník námětů a symbolů ve výtvarném umění, Praha 1991, s. 191.

48 Jednou z nejstarších soch zobrazujících sv. Jana Nepomuckého jako almužníka je socha, která stávala u kostela sv. Mikuláše na Starém Městě a která byla přenesena a osazena na sokl jiné, krátce předtím poškozené sochy, jež stávala na Jánském náměstí u bývalého kostela kláštera cyriakủ. Socha je dílem Ferdinanda Maxmiliána Brokoffa $\mathrm{z}$ doby okolo roku 1725 a dnes stojí společně se zmíněným podstavcem před staroměstským kostelem sv. Ducha. Srovnej viz Blažíček (pozn. 20), s. 135.

49 Důraz položený na Janovu lásku k bližnímu, která se projevovala jeho péćí o chudé, vdovy i sirotky se objevuje již ve světcově životopisu od Jana Ignáce Dlouhoveského z roku 1668 a později pak také v Balbínově verzi z let 1670-1671. K tomu viz Vít Vlnas - Jan Royt, Svatojánský kult v zrcadle písemných pramenů a knižních ilustrací, in: Svatý Jan Nepomucký 1393 * 1993 (pozn. 3), s. 61-62. V katalogu k této výstavě se nalézá mědiryt z roku 1664 znázorňující sv. Jana Nepomuckého jako almužníka. Ibidem, katalogové heslo 17, s. 88.

50 Postava Caritas byla součástí zásadní úpravy světcova hrobu v době mezi lety 1689-1694. Viz Matsche (pozn. 40), s. 49. 
k bližnímu svému, lásky, která nezná hranic, která se nebojí žádné oběti a která je vždy ochotna pomoci.

Přestože $\mathrm{v}$ př́ípadě této dvojice soch nemůžeme $\mathrm{k}$ jejich původnímu urbanistickému významu využít starší mapové podklady ani žádné podrobnější informace, které by nám napomohly lépe rekonstruovat jejich původní situaci, ${ }^{51} \mathrm{i}$ u nich můžeme předpokládat, že plnili roli průvodců daným výsekem prostoru. Vzhledem $\mathrm{k}$ tomu, že stály u vstupu do kaple Panny Marie Pomocné, můžeme říci, že vítali ty, kteří vstupovali do tohoto sakrálního prostoru a kteří se utíkali k Panně Marii a Čtrnácti svatým Pomocníkům s prosbou o pomoc v nějaké těžké životní chvíli, at už se jednalo o vážnou nemoc, či těžké zranění jich samotných, nebo o někoho jim blízkého.

Dnes sice obě sochy i nadále stojí v prostoru před klášterním kostelem, ovšem kaple, k níž se kdysi těsně vázaly, beze stopy zmizela a sochy samotné byly, bohužel, rozestavěny tak, že vás někdejší spojení mezi oběma díly, a tím pádem ani jejich původní smysl, na první pohled rozhodně nenapadne. ${ }^{52}$ Dvojici soch složenou původně ze sv. Jana Nepomuckého a sv. Jana $\mathrm{z}$ Boha zde totiž $\mathrm{v}$ současnosti $\mathrm{v}$ daném prostoru doplňuje socha sv. Antonína Paduánského, o jejímž původu zatím nic jistého nevíme. ${ }^{53}$ I u této dvojice statuí, stejně jako $v$ předchozích dvou př́padech, je tedy zřejmé, že změna charakteru jejich stanoviště a s ním související přesun těchto soch na stávající místo, vedlo ke ztrátě podstatné části jejich někdejší výpovědi.

\section{Případ čtvrtý - socha sv. Jana Nepomuckého ve Spálené ulici}

Poslední statuí věnovanou sv. Janu Nepomuckému, která se objevila na území tehdejších měst pražských ještě před blahořečením světce $\mathrm{v}$ roce 1721 , byla socha vztyčená v těsné návaznosti na nedávno dokončené průčelí kostela Nejsvětější Trojice kláštera trinitářů ve Spálené ulici na Novém Městě. ${ }^{54}$ Původně tato socha stávala v jakési nice v podobě konkávně tvarovaného úseku ohradní zdi vybíhající z pravého konce vstupního průčelí kostela, jak to zachycuje Jüttnerův plán, ${ }^{55}$ ale také originál císařského stabilního

51 Jediným relevantním zdrojem je zmínka nacházející se u Ekerta, že sochy stávaly u vstupu do kaple. Viz Ekert (pozn. 43). - Dostupné mapové podklady tyto sochy nezachycují, snad právě proto, že stály těsně u dané stavby a byly tak víceméně její součástí. Srovnej in: http://towns.hiu.cas.cz/p_zoom .php?map=AMP_Herget_1791, vyhledáno dne 25. 5. 2020. - http://mapy.vugtk.cz/praha/sheets .php?rs=1\&id=00\&map=juttner\&print, vyhledáno dne 21. 2. 2020.

52 Vzhledem $\mathrm{k}$ dané situaci vám spojení mezi sochami sv. Janů vytane na mysli jedině, když si lépe prohlédnete podstavce všech tří soch a také jejich sochařské provedení. V př́padě soch sv. Jana Nepomuckého a sv. Jana z Boha je za autora považován Jan Oldřich Mayer. V př́ípadě sochy sv. Antonína Paduánského není autor určen. Viz Batková (ed.), (pozn. 42), s. 716-717.

53 František Ekert se o ní vůbec nezmiňuje a v soupise uměleckých památek hlavního města Prahy není $\mathrm{k}$ jejímu původu ani $\mathrm{k}$ tomu, kdy se ocitla v tomto prostoru, nic bližšího uvedeno. Viz Ekert (pozn. 43). - Batková (ed.), (pozn. 42), s. 716-717.

54 Naposledy in: Tischerová (pozn. 10), s. 414. Dále viz Batková (ed.) (pozn. 42), s. 717. - Václav Vančura, Dílna Matouše Václava Jäckela, in: Umění XLII, Praha 1994, s. 199 a 208. - Miloš Suchomel, Bozzetto Matthiase Rauchmillera - efektní kompoziční předloha I, in: Zprávy památkové péče LII, Praha 1993, s. 337-338. - Emanuel Poche, Prahou krok za krokem, Praha 1985, s. 250.

$55 \mathrm{Viz}$ http://mapy.vugtk.cz/praha/sheets.php?rs=1\&id=00\&map=juttner\&print, vyhledáno dne 21. 2. 2020 . 
katastru. ${ }^{56}$ Dnes je umístěna v kubistické nice, jejíž architektonické řešení připojuje tuto sochu spíše k sousednímu domu Diamant. ${ }^{57}$

I když se jedná o velmi zajímavé dílo z hlediska ikonografického programu, celkového řešení statue, provedení architektury podstavce, ale i sochařských kvalit trojice postav sousoší, prozatím mu nebyla věnována náležitá pozornost. ${ }^{58}$ Nevíme tak nic konkrétního nejen o donátorovi tohoto díla, ale ani o jeho autorovi či autorech. Někdy bývá tato socha spojována s ateliérem Jana Brokoffa, ${ }^{59}$ konkrétně bud's osobností Ferdinanda Maxmiliána ${ }^{60}$ nebo jeho staršího bratra Michala Jana Josefa Brokoffa, ${ }^{61}$ jindy se zase uvažuje o okruhu Matěje Václava Jäckela. ${ }^{62}$

A nejen to, dokonce ani s jistotou nevíme, kdy tato statue vlastně vznikla. Obvykle bývá datována do roku $1717,{ }^{63}$ na soše samotné však najdeme hned několik nápisů, které v literatuře zavedenou dataci poněkud upravují. Přímo na plintu sochy světce je na čelní straně ve dvou řádcích vysekán nápis, který ukrývá chronogram 1718: „DICentI Ioannes aVe / NepoMVCene faVe“, tedy „Bud’ pozdraven milý Jane Nepomucký“ ${ }^{64}$ Další chronogram se stejným součtem zvýrazněných písmen najdeme v nápisu na dříku podstavce pod sochou. Ten je ale na několika místech značně poškozený, takže nejen některá písmena, ale i celé části slov nelze s jistotou identifikovat. Přesto zde nabízím jeho pravděpodobný přepis:

„(pI)a IoannIs InterCe(ss)I(o)

sIt nobIs

(a) ConfVsIone praeserV(at)I(o)

(p)eCCatorIbVs ConVersIo

(p)oenItentIbVs VenIa.

(f)IDeLIbVs DefVnCtIs

(r)eqVIes perpetVa“65

56 Viz https://archivnimapy.cuzk.cz/uazk/omc/omc_pom/omc_wms_01.html? mapfile=5752_14\& image_dir $=5752 \&$ maxextent $=0,-6932,8457,0$, vyhledáno dne 21.2. 2020. Umístění, které zachycují oba zmíněné plány, popisuje i František Ekert, ovšem s tím, že v té době byla socha vsazena do v roce 1863 nově zřízeného výklenku. Viz Ekert (pozn. 11), s. 77.

57 Autorem kubistického výklenku je pravděpodobně Antonín Pfeiffer. K tomu nejlépe in: Zdeněk Wirth, Ohrožený pohled na kostel sv. Trojice, Za starou Prahu: Věstník Klubu Za starou Prahu III, 1912, Praha 1913, s. 2, obr. 1-2, a dále Zdeněk Wirth, Socha Jana Nepomuckého ve Spálené ulici, Véstník Klubu Za starou Prahu III, 1912, Praha 1913, s. 78, obr. 102. - Batková (ed.) (pozn. 42), s. 717.

58 Nejvíce se mu věnovala Jana Tischerová, která, objevila pramen, který se vztahuje ke svěcení sochy. Ale i ona svou analýzu soustředí v prvé řadě na sochařské ztvárnění sochy světce, což je bohužel pro její pochopení málo. Viz Tischerová (pozn. 54).

59 Opatrně o něm uvažuje Tischerová. Viz Tischerová (pozn. 54).

60 O jeho autorství uvažuje Emanuel Poche. Viz Poche (pozn. 54).

61 Tento názor zastává Miloš Suchomel. Viz Suchomel (pozn. 54).

62 Do okruhu děl spojených s M. V. Jäckelem jej klade Vančura, naopak Tischerová jeho autorství vylučuje. Viz Vančura (pozn. 54).

63 Viz Tischerová (pozn. 54). - Batková (ed.) (pozn. 54). - Vančura (pozn. 54). - Suchomel (pozn. 54). Poche (pozn. 54).

${ }^{64}$ Jana Tischerová uvádí na základě nalezených pramenů, že socha byla svěcena 15. 5. 1719. Nápisy nacházející se na soše však asi bohužel důsledně nepřečetla, podobně jako její předchůdci. Viz Tischerová (pozn. 10), s. 414 a s. 586, pozn. č. 1634.

65 Vzhledem k okolnostem se přikláním k tomu, že socha vznikla až v roce $1718 \mathrm{~s} \mathrm{tím,} \mathrm{že} \mathrm{k} \mathrm{jejímu} \mathrm{slav-}$ nostnímu svěcení došlo v nejbližším termínu svátku světce. Viz pozn. 64 . 
V překladu tedy nejspíše:

„Skrze zbožnou přímluvu Jana

dejž nám

od zmatku uchránění

hř́šníkům obrácení,

kajícníkům milost,

věrným zesnulým

věčný odpočinek." ${ }^{\circ 6}$

Ponechme nyní stranou prŕípadnou otázku autorství či přesného data vzniku díla a věnujme se samotné soše, která je opravdu po všech stránkách nesmírně zajímavá a jejíž podoba mimo jiné svědčí o určitých ambicích objednavatele tohoto díla.

Jak už bylo řečeno, stála socha původně $\mathrm{v}$ konkávně tvarovaném úseku ohradní zdi, který vybíhal přímo z pravého nároží hlavního průčelí kostela a který společně s podobně tvarovaným úsekem zdi na druhém konci vstupní fasády objektu vytvářel prostorovou jímku, jež podtrhovala skutečnost, že budova nového klášterního kostela rádu trinitářu poněkud ustupuje od linie uliční čáry. Cílem nejspiše bylo vytvořit zde určitý prostor pro to, aby věřící shromaždující se před kostelem před bohoslužbou nebo po ní nebránili př́liš plynulému provozu ve Spálené ulici, ale také poukázat na to, že se ocitáte na místě s odlišným duchovním obsahem. Už z toho je zřejmé, že socha byla začleněna do komplexně pojatého urbanistického záměru.

O snaze propojit pevně sochu s daným místem svědčí to, že tvar samotného podstavce sleduje mírně konkávně se propadající křivku. To však není to jediné, čím se tento podstavec odlišuje od obvyklých daleko jednodušších hranolových soklů té doby. Zdvíhá se sice z nepř́iliš vysoké nijak zvlášt zajímavé patky, ale jeho dř́k je modelován do podoby organické srostlice centrálního hranolového útvaru obloženého na čelní straně deskou a konkávně projmutých křídel, které se v horní části zavíjejí do volut. Volutová křídla pak spolu vynášejí úsek kompletního kladí tvořeného nad kř́dly stlačeným kanelovaným vlysem. Nad úsekem odpovídajícím obložení jádra dříku mohutnou deskou se pak tento úsek vlysu ještě konvexně zdvíhá směrem vzhůru. Na vzniklé prokrajované ploše je umístěno pole, na němž se vznáší pětice hvězd, která se objevila nad mrtvým tělem světce poté, co jej Vltava vyplavila na břeh nedaleko kláštera cyriaků.

Tento měkce modelovaný vlys ukončuje prstenec, na který nasedá další tentokrát už hladký vlys, jenž uzavírá bohatě profilovaná výrazně vysazená římsa. Oba zmíněné horizontální prvky přitom opakují konvexně vzhůru stoupající křivku určenou dolním vlysem. Většina plochy dříku obloženého deskou je vyplněna dalším oblamovaným polem ukončeným na spodním okraji dvojicí spojených volut a dvěma trojicemi kapek připomínajících jakési střapce. Toto pole je určeno hlavnímu votivnímu nápisu, který, jak jsme viděli, řadí světce mezi významné př́mluvce na nebesích.

Další důležitý nápis je pak vysekán v horním hladkém vlysu podstavce. Jedná se o parafrázi textu knihy Přísloví kapitoly IV., verše 18., který v překladu v úplnosti zní: „Ale stezka spravedlivých jest jako světlo jasné (kteréž rozmáhá se, a svití, až se ukáže pravý den). “67 Na tento verš pak navazují slova, která se vztahují k bezbožným: „Cesta pak bez-

${ }^{66}$ Za pomoc s doplněním chybějících písmen a překladem nápisu děkuji PhDr. Pavlu Zahradníkovi.

67 V originále nápis zní: „IVSTI SEMITA / QVASI / LVX SPLENDENS / PROVERB: IV. V: XVIII.“ 
božných jako mrákota, nevědí, na čem se ustrčiti mohou. "Sv. Jan je zde přirovnán k oněm spravedlivým, jejichž stezka je jako světlo jasné, které se rozmáhá a svítí. To znamená, že nám sv. Jan svým životem i svou smrtí ukázal cestu, cestu následování slova Božího, cestu, těch, kteří milují Boha, a proto nikdy nezbloudí. Nebot zdrojem světla, které osvětluje cesty spravedlivých, je samozřejmě Bůh. Současně se zde objevuje eschatologický akcent, protože okamžikem, kdy dojde $\mathrm{k}$ tomuto osvícení, je samozřejmě Poslední soud („ǎ̌ se ukáže pravý den"). Světlo, které je hlavním motivem daného verše z knihy Př́íloví, můžeme rovněž chápat jako aluzi na pětici světel, která obklopila Janovo tělo a která jsou v podobě pěti šesticípých hvězd vysekána přímo pod tímto nápisem.

Sochařskou část statue podobně jako v prrípadě sochy stojící u paty Radnických schodů tvoří skupina, složená z postavy světce variující kompozici mostecké sochy a dvou postaviček andílkủ, kteří usedli po stranách plintu na bočních úsecích svrchní strany římsy podstavce. A podobně jako $\mathrm{v}$ př́padě hradčanské sochy ani zde se nejedná o pouhou stafáž. I tito andílci propojují svými gesty a pohledy světce s kolemjdoucími, a tím, jak se jejich tělíčka vytáčejí směrem ke stř̌ední ose, vytvářejí společně se sochou sv. Jana konkávně tvarovanou prostorovou jímku, navazující na křivku, do které je tvarován podstavec.

Důležitou roli hrají tito andílci také v ideovém programu statue. Nedrží sice obvyklé atributy světce, ale předměty, konkrétně štít a knihu, do kterých jsou vysekány další neobvyklé nápisy. Tyto jsou sice ještě více poškozené než hlavní nápis na dř́ku podstavce sochy, ${ }^{68}$ ovšem naštěstí obsahují podobně jako úryvek z knihy Př́sloví vysekaný do plochy vlysu výňatky ze Starého zákona, proto je možné je rekonstruovat. Na štítě, který přidržuje levý andílek zmíněný nápis v úplnosti nejspíše zněl:

„STETIT / CONTRA REGES HORRENDOS / I PORTE(NTIS) / SIGNIS / SAP: (X:XVI). "Jedná se o verš z knihy Moudrosti, deuterokanonické části Bible, který celý zní: „Intravit in animam servi Domini et stetit contra reges horrendos in portentis et signis. “, tedy „Vstoupila do duše Božího služebníka a postavila se proti děsivým králům v divech a znameních." Tento odkaz můžeme chápat jako narážku na příběh o zpovědním tajemství, na okamžik, kdy se sv. Jan Nepomucký vzepřel králi Václavovi IV. a odepřel mu prozradit obsah zpovědi královny Žofie. Vedle toho však opět můžeme tento verš interpretovat i v návaznosti na verš následující, jako další odkaz na Poslední soud. V následujícím verši se totiž objevuje: „Et reddidit justis mercedem laborum suorum, et deduxit illos in via mirabili, et fuit illis in velamento diei, et in luce stellarum per noctem", to jest „A odméňovala spravedlivou mzdu za jejich práci a vedla je úžasným způsobem: a byla pro ně ve dne skrytá a v noci pro světlo hvězd." V tomto verši se navíc znovu nachází odkaz na světlo a současně na něco, co zůstává skryté, na nějaké tajemství.

Další dva nápisy byly vysekány do rozevřené knihy, kterou drží pravý andílek. Na levé straně knihy se pravděpodobně původně nacházelo: „BEATVS VIR / QVI (NO)N EST / $\mathrm{LAP}(\mathrm{SV})(\mathrm{V}) \mathrm{ERBO} /$ / $\mathrm{EX})$ / ORE S(VO) / EC(CL)ES: (XIV:I)." Jedná se o další verš z jiného deuterokanonického textu, tentokrát z tzv. Sírachovce či knihy Sírachovcovy, latinsky zvané Liber ecclesiasticus. Tento verš v úplnosti zní: „Beatus vir, qui non est lapsus verbo ex ore suo et non est stimulatus in tristitia delicti.“ („Blaze člověku, který se

68 Tato část celého díla byla, bohužel, opakovaně postižena hloubkovou korozí kamene a značné části obou andílků včetně předmětů, které přidržují, dnes tvoří modelační doplňky z materiálu na bázi umělého kamene. 
neprohřešil svými ústy a nezakusil trýzeň zármutku pro své hříchy. ") ${ }^{69}$. Znovu se tedy jedná o narážku na př́činu Janovy mučednické smrti. K témuž pak odkazuje i nápis na pravé straně knihy, jenž tentokrát znovu čerpá z knihy Př́ísloví: „GLORIA DEI / EST / C(ELA) RE VERB(VM) / PROVE(RB: XXV:II).“, tedy „Sláva Boží jestit skrývati věc. “ Tedy opět narážka na tajemství, na cosi, co má zůstat skryto.

Z analýzy celkového rozvrhu sousoší, ale i tvarově velmi nápaditého podstavce, je zřejmé, že cílem objednavatele bylo vytvořit dílo, které by oslavilo sv. Jana jako jednu z význačných osobností dějin spásy. Jedině tak lze vysvětlit, proč vedle obvyklé formy textu votivního nápisu, s jakým jsme se setkali např́íklad na soše sv. Jana Nepomuckého u kostela sv. Jindřicha na Novém Městě, sáhl autor celkového ikonografického programu sochy k výňatkům ze Starého zákona, a to navíc nejen z neprŕliš často citované knihy Přísloví, ale také z deuterokanonické knihy Moudrosti a knihy Sírachovcovy, jejichž texty byly součástí nové edice Vulgaty, iniciované papežem Sixtem V., který si jako jeden z hlavních úkolů svého pontifikátu vytkl uvést závěry tridentských koncilů do praxe. ${ }^{70}$

Právě poslední uvedené snad nejvíce ze všeho napovídá, že donátora tohoto díla bychom měli hledat v řadách vysoce postaveného kléru, nejspíš mezi tehdejšími kanovníky působícími při chrámu sv. Víta nebo osobnostmi př́mo spojenými s novým klášterem trinitářů. Možností je hned několik. O to, že se v Praze trinitáři usadili, se mimo jiné zasloužil kř́ižovník Jan František Beckovský, autor Poselkyně starých př́iběhů českých. Vysvěcení kostela Nejsvětější Trojice proběhlo za účasti tehdejšího světícího biskupa pražského Daniela Josefa Mayera ${ }^{71}$ a sochu samotnou pak, jak doložila Jana Tischerová, světil staroboleslavský kanovník Josef Benedikt Schönpflug z Gamsenberka. ${ }^{72}$

Těžko říct, zda se již v okamžiku vzniku této sochy uvažovalo o tom, že i ona bude mít svého souputníka. Faktem je, že tentokrát na něj sv. Jan čekal poměrně dlouho, téměř patnáct let. Teprve v roce 1732 byla na druhém konci hlavního průčelí klášterního kostela trinitář postavena socha sv. Judy Tadeáše a opět se jedná o dílo, o jehož vzniku toho mnoho nevíme. Hlavním zdrojem informací o něm se tak podobně jako $\mathrm{v}$ př́padě sochy sv. Jana Nepomuckého stává samotná statue. Datace jejího vzniku je zaznamenána také přímo na podstavci, a to v chronogramu nápisu, který je vysekán v hladkém úseku horního vlysu na čelní straně: „hIC sTaT DesperanTVm VerVs / eT VnICVs paTronVs“, „Zde stojí pravý a jediný ochránce všech zoufalých“. Kromě samotného chronogramu s rokem vztyčení statue 1732 se tak dovídáme, že i tato socha prezentuje apoštola sv. Judu Tadeáše, jako ochránce těch, kteří už ztratili veškerou naději.

Co je však ještě pozoruhodnější, podíváte-li se na celkovou podobu obou statuí, pak je zřejmé, že navzdory takřka patnáctiletému odstupu usiloval donátor sochy sv. Judy Tadeáše o to, aby se sochy staly svými zrcadlovými protějšky, a aby tak společně s průčelím trinitářského kostela vznikla specifická trojdílná kompozice. Totožné je nejen řešení podstavce, ale i sochařská část statue je rozvržena podobným způsobem. To znamená, že také sochu sv. Judy Tadeáše doprovází dvojice malých andílků usazených na svrchní straně římsy podstavce. Drobné rozdíly se projevují jen v proporcích některých částí a jejich kamenickém zpracování.

${ }^{69}$ Český ekumenický překlad př́stupný na: http://www.biblenet.cz/b/Sir/14, vyhledáno dne 29. 9. 2020.

70 Torgil Magnuson, Rome in the Age of Bernini, Uppsala 1982, s. 32.

71 Tyto skutečnosti zmiňuje mimo jiné František Ekert. Viz Ekert (pozn. 11), s. 76-77.

72 Tischerová (pozn. 64). 
V tomto uspořádání stály sochy obou světců více jak sto třicet let, přičemž jejich situaci v dané části Spálené ulice zachycuje ještě císařský stabilní katastr, kde můžeme dobře vidět oba konkávně skrojené úseky zdi, do nichž byly sochy sv. Jana Nepomuckého a sv. Judy Tadeáše zasazeny. ${ }^{73}$ To znamená, že kompoziční řešení přežilo jak zrušení kláštera v době josefínských reforem, tak i následující postupné proměny dané části území Nového Města. K prvnímu částečnému roztržení obou světců došlo až v roce 1863 , kdy neznámá dobrodinka nechala okolo sochy sv. Jana Nepomuckého vybudovat z pískovce novou výklenkovou kapli. ${ }^{74}$ Navzdory tomu, že její architektonické řešení volbou tvarosloví, ale i celkovou skladbou vycházelo z architektonického rozvrhu hlavního průčelí kostela, přispěl tento zvelebující zásah $\mathrm{k}$ tomu, že už obě sochy nevedly tak přesvědčivě zamýšlený dialog.

K definitivnímu roztržení obou soch pak došlo v době, kdy dům stojící na nároží Spálené a dnešní Lazarské ulice získal svou stávající a z mnoha důvodů dnes oceňovanou podobu, v níž se odráží aktuální dobové výtvarné trendy. V té době byl nejen upraven prostor mezi domem zvaným Diamant a bočním průčelím kostela Nejsvětější Trojice tak, že zde vzniklo malé nehostinné tmavé zákoutí, do nějž byla přenesena také neobarokní výklenková kaple určená původně pro sochu sv. Jana. ${ }^{75} \mathrm{~V}$ těsné návaznosti na dokončení domu vznikla rovněž stávající kubisticky formovaná nika. ${ }^{76}$ Navzdory tomu, že z pohledu původní lokace sochy zdánlivě nedošlo k nijak zásadní změně, vedla tato úprava $\mathrm{k}$ tak radikální transformaci jejího nejbližšího kontextu, že valná většina kolemjdoucích si už dnes neuvědomí, že tato socha má jen kousíček od sebe svou druhou polovinu, s níž kdysi tvořila zajímavou formální i obsahovou kompozici, dotvářející navíc významným způsobem charakter prostranství před klášterním kostelem.

$\mathrm{Na}$ rozdíl od Zdeňka Wirtha se domnívám, že z hlediska absolutních výtvarných kvalit tvoří socha sv. Jana Nepomuckého s architektonicky zajímavě řešeným kubisticky laděným výklenkem harmonický celek. ${ }^{77} \mathrm{~A} z$ tohoto pohledu tomuto řešení nelze nic vytknout. Přesto však tímto novým umístěním sochy v kubistickém výklenku došlo k definitivnímu zániku určitých historických hodnot sochy, které souvisely s dobou jejího vzniku a se záměry a cíli donátorů či donátora obou soch, tedy nejen sv. Jana Nepomuckého, ale i jejího mladšího protějšku sv. Judy Tadeáše. Příběh této dvojice, ale vlastně i všech ostatních sochařských párů, jimiž jsme se zde zabývali, by se tak měl stát jakýmsi mementem při jakémkoliv dalším rozhodování o transferech sochařských děl či jejich reinstalaci. Jejich sepětí s konkrétním místem totiž může být, jak jsme opakovaně viděli, daleko těsnější, než se nám na první pohled zdá a než třeba v danou chvíli dokážeme na základě našich stávajících znalostí a vědomostí rozpoznat.

Předložené analýzy dotčených statuí totiž mimo jiné ukázaly, že výsledkem takovýchto původně především ikonograficky a teologicky motivovaných propojení byly zajímavé výtvarné kompozice, které proměňovaly a obohacovaly vzhled dotčených veřejných pro-

73 Viz https://archivnimapy.cuzk.cz/uazk/omc/omc_pom/omc_wms_01.html?mapfile=5752_14\&image dir $=5752 \&$ maxextent $=0,-6932,8457,0$, vyhledáno dne 21. 2. 2020.

74 Ekert (pozn. 56).

75 Viz pozn. 57.

76 Ibidem.

77 Zdeněk Wirth kritizoval především to, že nika vytváŕí pro sochu „děravý rámec“. Mimoto se mu také nelíbilo, kam byla přesunuta architektura rámující sochu od roku 1863 a jak bylo toto prostranství pojato. Viz pozn. 56. 
stranství tehdejších měst pražských. Bohužel, kdysi zjevné důvody a motivy objednavatelů pro vytvoření těchto sochařských párů, které vedly k jejich vzniku, se postupem času stávaly méně zjevné, až se staly v podstatě obtížně identifikovatelné a jejich někdejší těsná vazba s daným místem i její prríčiny úplně upadly v zapomenutí. Výrazný podíl na tom měl právě i provedený přesun soch a proměna jejich původního umístění.

Některé z př́padů světeckých párů, jimiž jsme se zde zabývali, nejsou jen dokladem „barokního přístupu“ $\mathrm{k}$ instalaci sochařských děl ve veřejném prostoru, dobové snahy těmito pomníky dané místo pointovat a naplnit jej konkrétními významy přesahujícími naši každodennost. Poukazují také na jev, který by pravděpodobně bylo možné vysledovat i u jiných sochařských monumentů, které byly sv. Janu Nepomuckému postaveny ještě před jeho blahořečením. Totiž, jedním z motivů vzniku těchto světeckých párů, o kterém je nutné uvažovat, bylo legitimizovat votivní dílo věnované osobnosti, která z pohledu tehdy platných církevních předpisů na takový projev úcty plné právo ještě neměla. Postava Jana Nepomuckého je v těchto sochařských dvojicích, jak jsme viděli, doprovázena nejen zobrazeními jiných českých zemských patronů, ale setkává se zde také s osobnostmi z řad apoštolů nebo světců, kteří se v rámci reformy katolického vyznání pokusili apoštolský koncept znovu obnovit, a i proto se stali symboly tridentské reformy katolické církve.

Všechny uvedené prríklady soch zobrazujících sv. Jana Nepomuckého v době před jeho blahořečením byly, což si my dnes jen málokdy uvědomujeme, vlastně projekty s dosti nejistou budoucností. To, jak nejistý osud všechny tyto svým způsobem odvážné donátorské počiny v dané době měly, dokládá socha, která dnes stojí na rampě u Pražského hradu v místě vyústění Nových zámeckých schodů. Toto dílo pocházející z brokoffovského ateliéru původně představovalo blahoslaveného Jana Sarkandera a podobně jako uvedené sochy sv. Jana Nepomuckého bylo vytvořeno právě v době, kdy byly zahájeny první kroky k blahořečení tohoto moravského hrdiny. ${ }^{78}$ Na rozdíl od sv. Jana Nepomuckého však s prosazením kněze Jana Sarkandera mezi oficiálně uznané světce v této době Češi neuspěli, a tak byla tato statue nejpozději roku 1764 nejen přesunuta od Arcibiskupského paláce, kde původně stávala, ale hlavně byla pomocí vysekání nového votivního nápisu na čelní straně kartuše přidržované dvěma putti proměněna v sochu zakladatele řádu oratoriánů a patrona dobré smrti sv. Filipa z Neri.

\section{SUMMARY}

\section{(In)separable companions. Half-forgotten iconographic and urban contexts of selected sculptures dedicated to St. John of Nepomuk in Prague}

The article deals with several statues of St. John of Nepomuk, which were created on the territory of the former Prague cities between the erection of the statue of a saint on Charles Bridge in 1683 and his beatification in 1721. Based on a deeper analysis of avai-

78 Srov. alespoň Rudolf Zuber, Je svatořečení Jana Sarkandra oprávněné? in: Kněz a mučedník Jan Sarkander: Sborník ke svatořečení, Olomouc 1994, s. 74-99. 
lable data found both in the existing literature and on these statues themselves, and evaluation of their former urban context, the author points out an interesting phenomenon that is associated with these statues.

The statues of St. John of Nepomuk from the time when this Czech provincial patron was not yet officially recognized as a saint or blessed are often accompanied by a statue of another saint. Sometimes the second statue was built at the same time as the statue of St. John, another time a few years later. Each time, however, a pair was formed connected by a common ideological program, which also actively worked with the context of the place.

A later change of the character of the original site of the statues, either as a result of the transfer of the statue or due to the gradual change of the urban context of the place, led to all these pairs no longer perceiving their former fixed connection and thus missing a substantial part of their original meaning. One of the aims of the article is to rediscover these half-forgotten facts, which are an integral part of the story of these sculptural works. The second no less important aim of the article is to re-emphasize what appears here and there in the literature, so, how much the Baroque sculpture is connected not only with the time, but also with the place for which it was once created.

\section{VÝBĚROVÁ BIBLIOGRAFIE}

Růžena Batková (ed.), Umělecké památky Prahy. Nové Město, Vyšehrad, Vinohrady (Praha 1), Praha 1998. Oldřich Jakub Blažíček, Ferdinand Brokof, Praha 1986.

Oldřich Jakub Blažíček, Sochařství baroku v Čechách, Praha 1958.

Wolfgang Braunfels (ed.), Lexikon der christlichen Kunst, svazek 7, Rom-Freiburg-Basel-Wien 1994.

Nataša Brejchová-Steinová, Zjánštěná item zjančená léta na Děčínsku, Okresní muzeum Děčín 2001.

František Ekert, Posvátná mista královského hlavního města Prahy. Dějiny a popsání chrámů, kaplí, posvátných soch, klášterů a jiných pomníků katolické víry a nábožnosti v hlavním městě království Českého I, II, Praha 1883, 1884.

Karel Navrátil, Paměti hlavního kostela farního, fary a školy sv. Jindřicha a sv. Kunhuty v Novém Městě pražském, Praha 1869.

Julius Max Schottky, Prag wie es war und wie es ist, nach Aktestücken und den besten Quellenschriften geschildert, Prag 1832.

Svatý Jan Nepomucký 1393 * 1993 (katalog výstavy), Bavorské národní muzeum v Mnichově ve spolupráci s klášterem premonstrátů na Strahově v Praze a s Národním muzeem v Praze, Praha 1993.

Jana Tischerová, Matěj Václav Jäckel. Sochař českého baroka 1655-1738, Praha 2013.

Vít Vlnas, Jan Nepomucký: česká legenda, druhé vydání, Praha 2013.

Vít Vlnas, Jan Nepomucký, světec baroka aneb druhý život Johánka z Pomuku, in: Václav Chroust Zdeňka Buršíková - Karel Viták (eds), Pět hvězd nad českým královstvím: svatý Jan Nepomucký a katolická reformace, svazek 1, Klatovy 2013, s. 49-78.

Pavel Vlček (ed.), Encyklopedie architektů, stavitelů, zedníků a kameníkův Čechách, Praha 2004.

Pavel Vlček (ed.), Umělecké památky Prahy. Pražský hrad a Hradčany, Praha 2000.

Zdeněk Wirth, Socha Jana Nepomuckého ve Spálené ulici, Věstník Klubu Za starou Prahu III, 1912, Praha 1913, s. 76-79. 


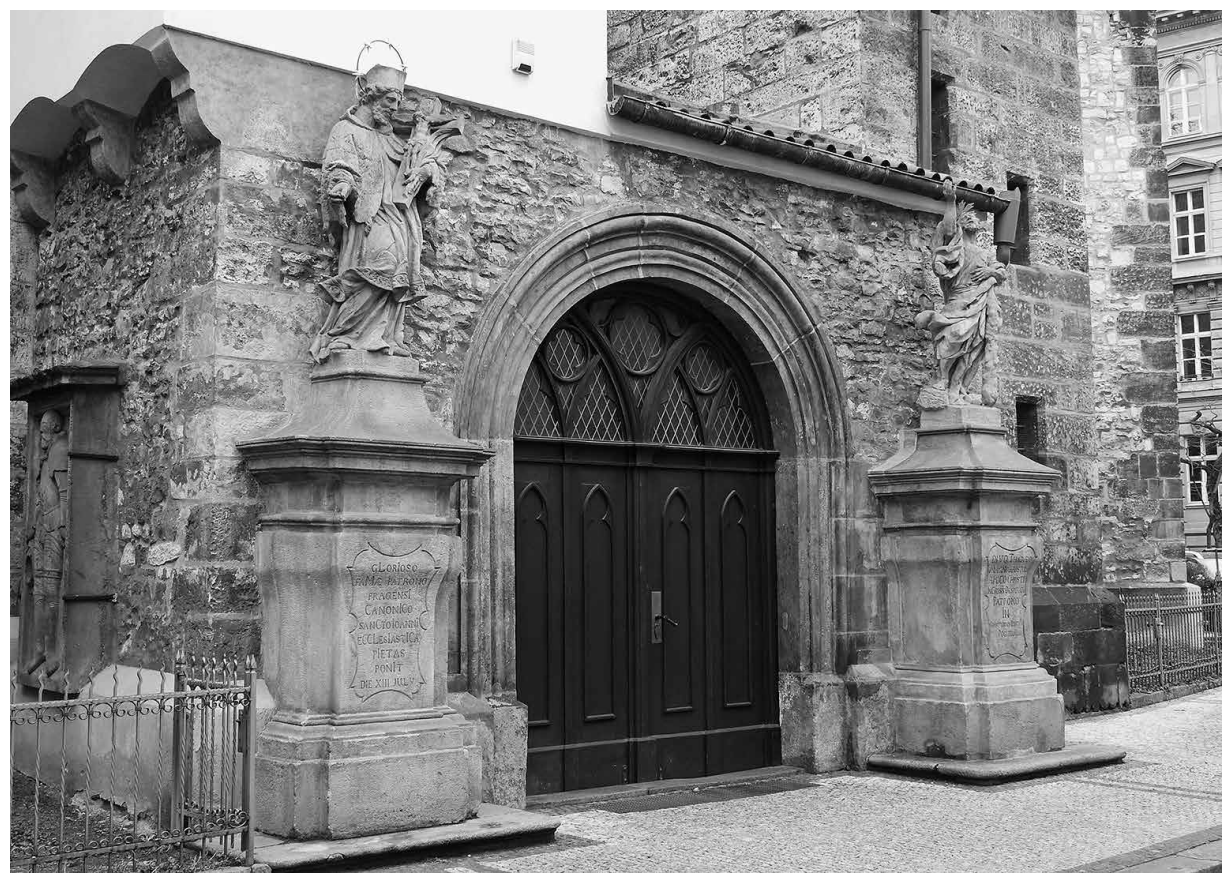

Obrázek 1. Sochy sv. Jana Nepomuckého a sv. Judy Tadeáše, 1709, u kostela sv. Jindřicha, Praha 1 - Nové Město, snímek Kateřina Adamcová, 2021

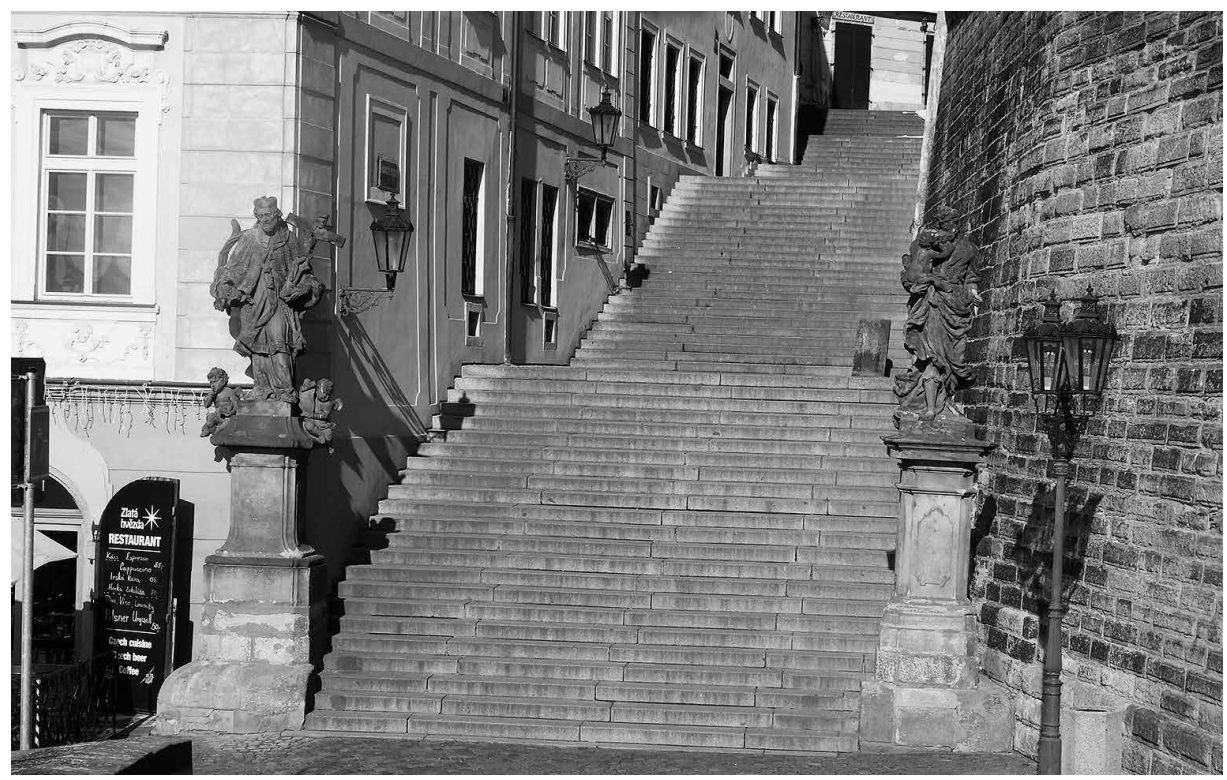

Obrázek 2. Sochy sv. Jana Nepomuckého a sv. Josefa, 1709 a 1714, u Radnických schodů, Praha 1 - Hradčany, snímek Kateřina Adamcová, 2020 


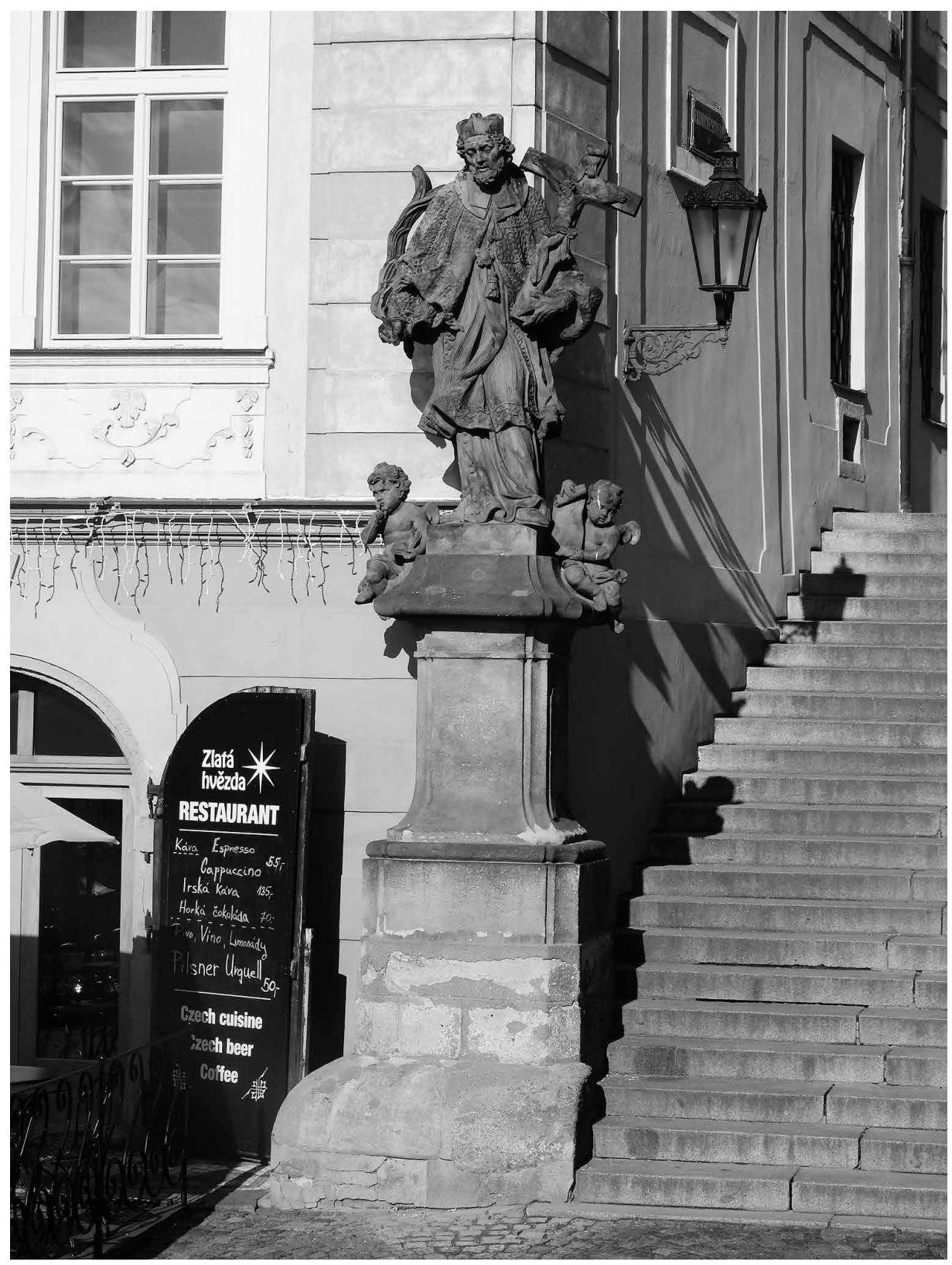

Obrázek 3. Ferdinand Maxmilián Brokof, František Jakub Santini, socha sv. Jana Nepomuckého, 1709, u Radnických schodů, Praha 1 - Hradčany, snímek Kateřina Adamcová, 2020 


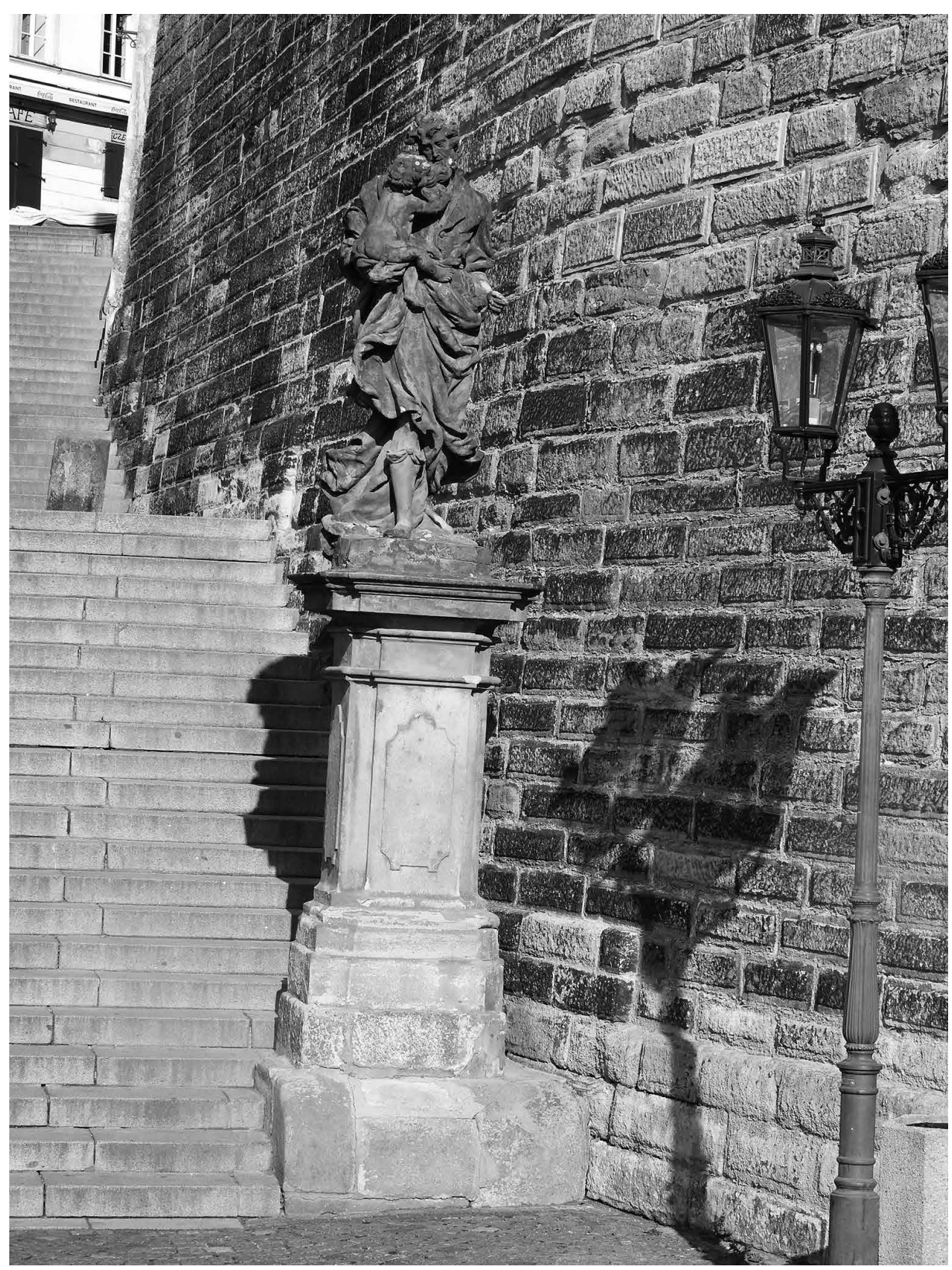

Obrázek 4. Matyáš Bernard Braun (?), socha sv. Josefa, 1714, u Radnických schodů, Praha 1-Hradčany, snímek Kateřina Adamcová, 2020 


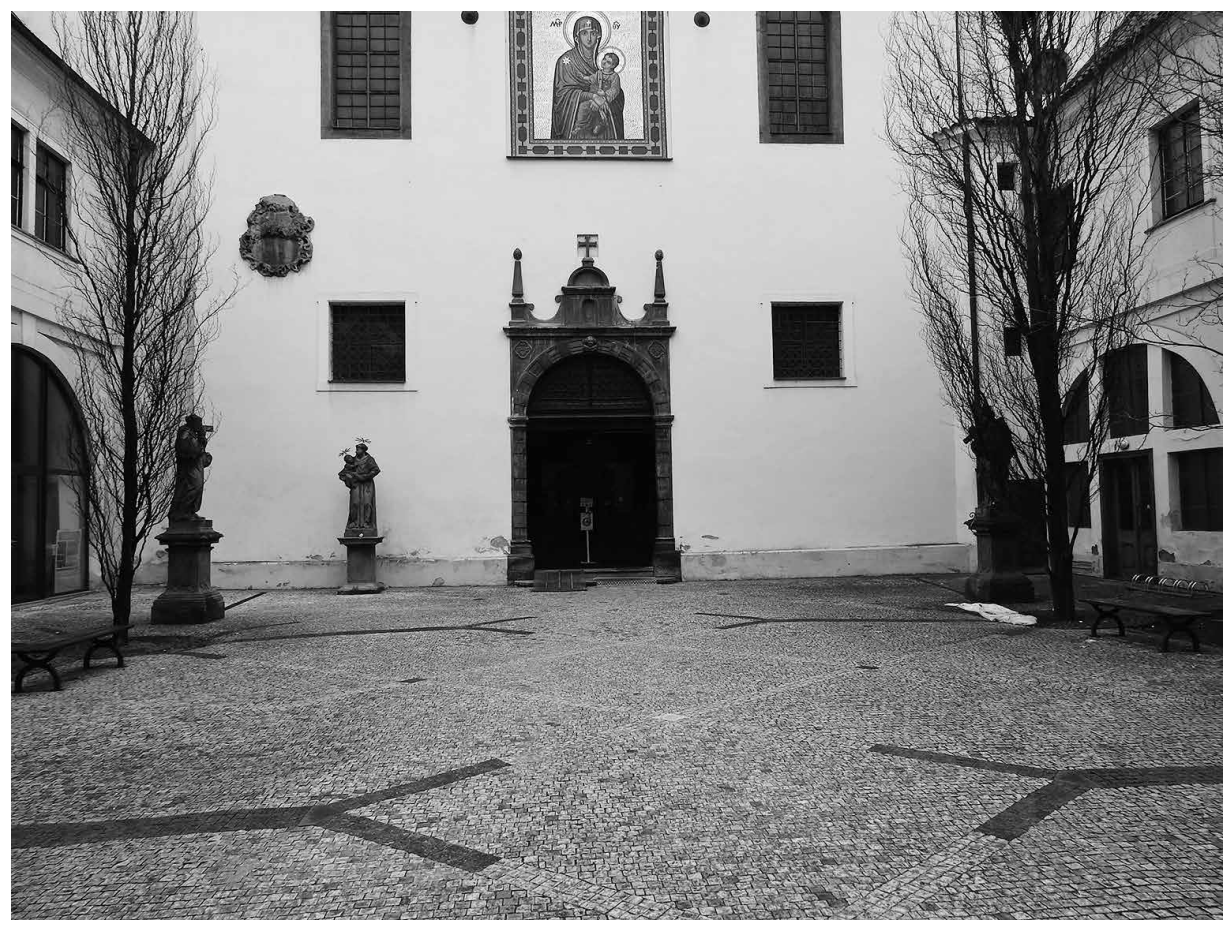

Obrázek 5. Nádvoří kostela Panny Marie Sněžné, Praha 1 - Nové Město, snímek Kateřina Adamcová, 2021 


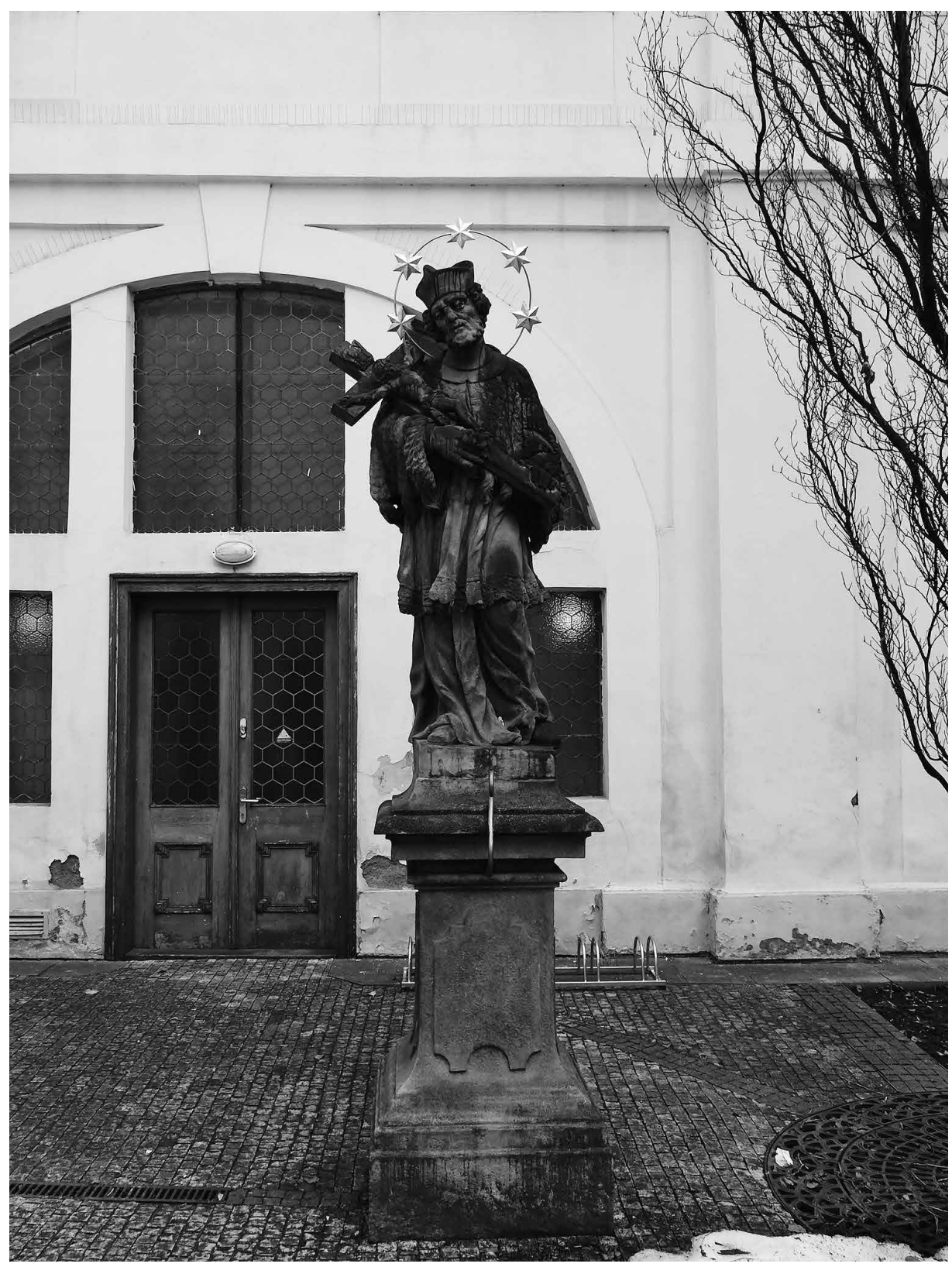

Obrázek 6. Jan Oldřich Mayer (?), socha sv. Jana Nepomuckého, 1715, nádvoří kostela Panny Marie Sněžné, Praha 1 - Nové Město, snímek Kateřina Adamcová, 2021 


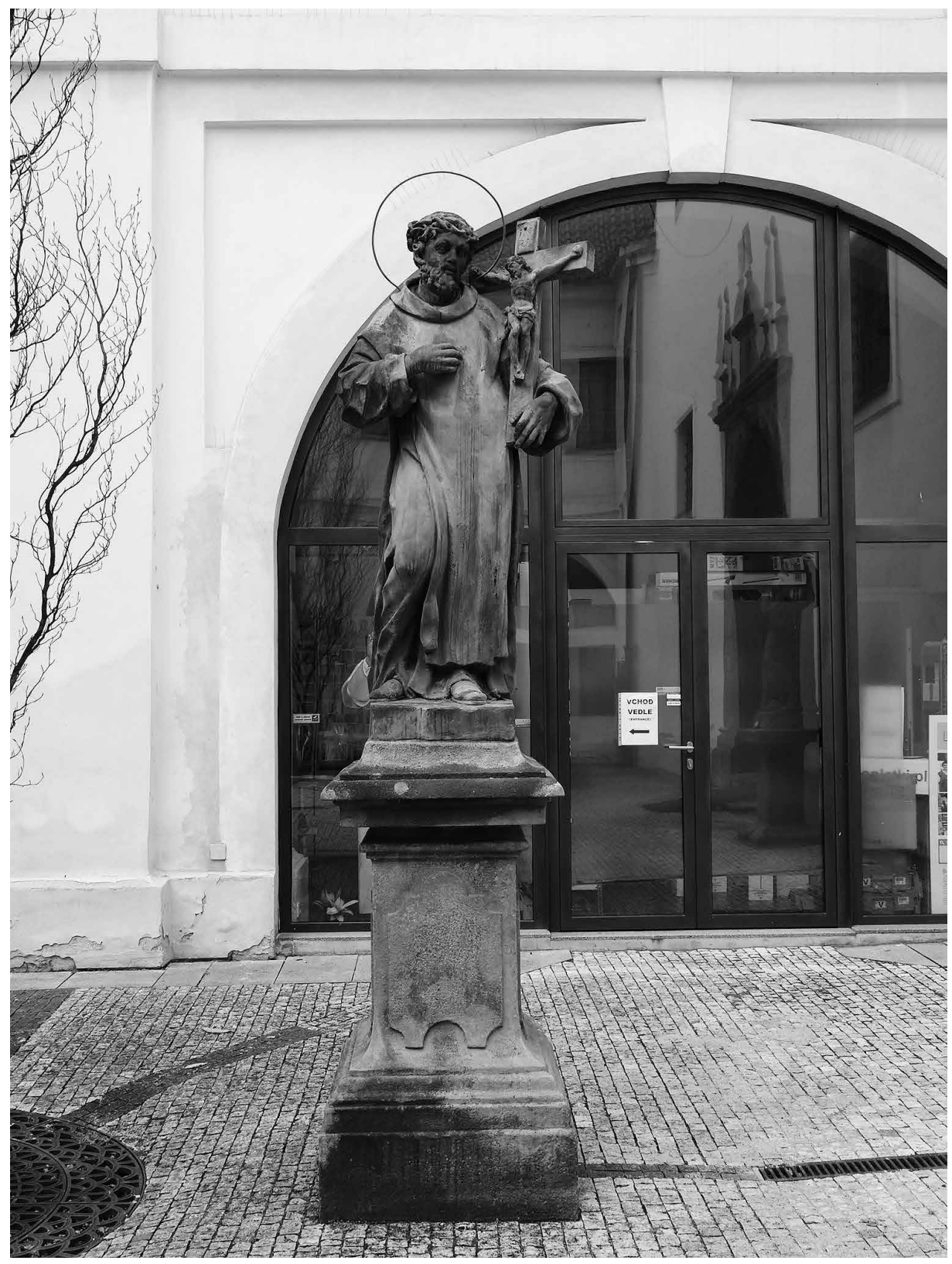

Obrázek 7. Jan Oldřich Mayer (?), socha sv. Jana z Boha, 1715, nádvoří kostela Panny Marie Sněžné, Praha 1 - Nové Město, snímek Kateřina Adamcová, 2021 


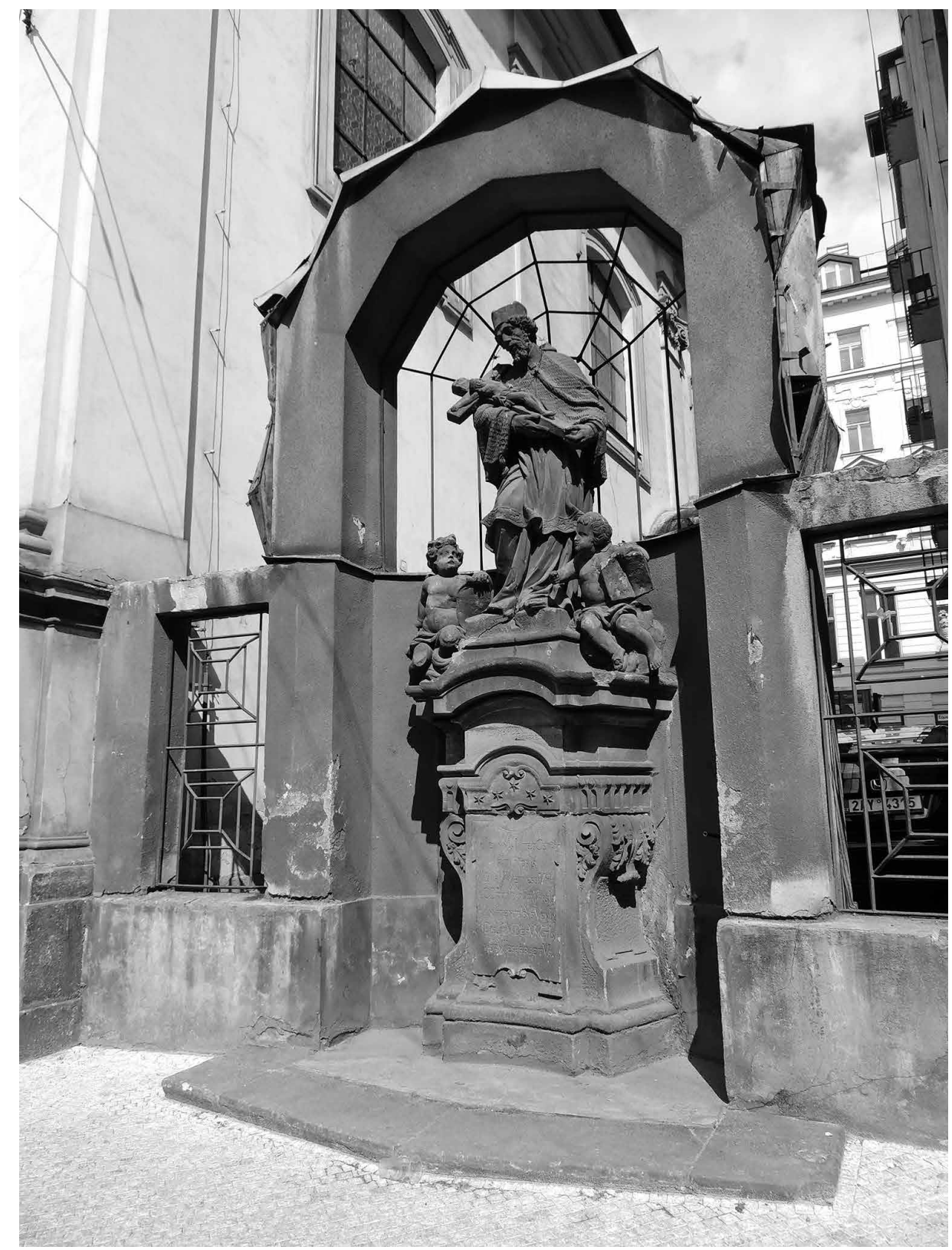

Obrázek 8. Matěj Václav Jäckel (okruh,), socha sv. Jana Nepomuckého, 1718, Spálená ulice, Praha 1 Nové Město, snímek Kateřina Adamcová, 2018 


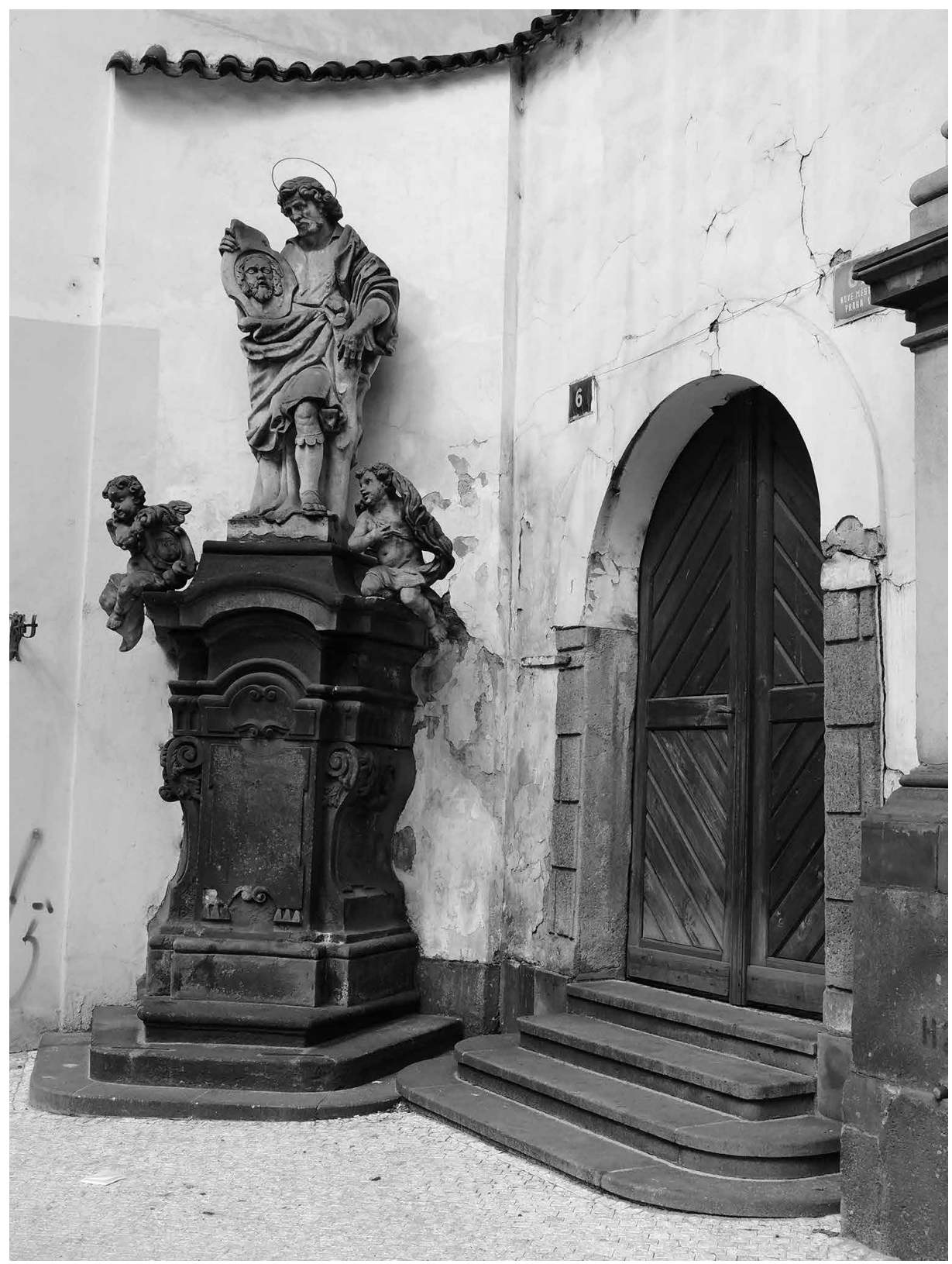

Obrázek 9. Socha sv. Jana Nepomuckého, 1732, Spálená ulice, Praha 1 - Nové Město, snímek Kateřina Adamcová, 2018 